\title{
A Central Extended Amygdala Circuit That Modulates Anxiety
}

\author{
Sandra Ahrens, Melody V. Wu, Alessandro Furlan, Ga-Ram Hwang, Raehum Paik, Haohong Li, Mario A. Penzo, \\ - $J e s s i c a$ Tollkuhn, and ${ }^{\circledR B}$ Bo Li \\ Cold Spring Harbor Laboratory, Cold Spring Harbor, New York 11724
}

Both the amygdala and the bed nucleus of the stria terminalis (BNST) have been implicated in maladaptive anxiety characteristics of anxiety disorders. However, the underlying circuit and cellular mechanisms have remained elusive. Here we show that mice with Erbb4 gene deficiency in somatostatin-expressing $\left(\mathrm{SOM}^{+}\right)$neurons exhibit heightened anxiety as measured in the elevated plus maze test and the open field test, two assays commonly used to assess anxiety-related behaviors in rodents. Using a combination of electrophysiological, molecular, genetic, and pharmacological techniques, we demonstrate that the abnormal anxiety in the mutant mice is caused by enhanced excitatory synaptic inputs onto $\mathrm{SOM}^{+}$neurons in the central amygdala (CeA), and the resulting reduction in inhibition onto downstream SOM ${ }^{+}$neurons in the BNST. Notably, our results indicate that an increase in dynorphin signaling in $\mathrm{SOM}^{+} \mathrm{CeA}$ neurons mediates the paradoxical reduction in inhibition onto $\mathrm{SOM}^{+}$BNST neurons, and that the consequent enhanced activity of SOM ${ }^{+} \mathrm{BNST}$ neurons is both necessary for and sufficient to drive the elevated anxiety. Finally, we show that the elevated anxiety and the associated synaptic dysfunctions and increased dynorphin signaling in the CeA-BNST circuit of the Erbb4 mutant mice can be recapitulated by stress in wild-type mice. Together, our results unravel previously unknown circuit and cellular processes in the central extended amygdala that can cause maladaptive anxiety.

Key words: anxiety; BNST; central amygdala; dynorphin; ErbB4; stress

\section{Significance Statement}

The central extended amygdala has been implicated in anxiety-related behaviors, but the underlying mechanisms are unclear. Here we found that somatostatin-expressing neurons in the central amygdala (CeA) controls anxiety through modulation of the stria terminalis, a process that is mediated by an increase in dynorphin signaling in the CeA. Our results reveal circuit and cellular dysfunctions that may account for maladaptive anxiety.

\section{Introduction}

Threatening environmental stimuli can induce both fear (the phasic emotional state induced by acute and explicit threats) and

Received March 18, 2018; revised April 22, 2018; accepted May 11, 2018.

Author contributions: S.A., M.V.W., A.F., J.T., and B.L. designed research;S.A., M.V.W., A.F., G.-R.H., R.P., H.L., and M.A.P. performed research; S.A., M.V.W., H.L., M.A.P., J.T., and A.F. analyzed data; B.L. wrote the paper.

The authors declare no competing financial interests.

This work was supported by the National Institutes of Health (Grant R01-MH-101214, B.L.), National Alliance for Research on Schizophrenia and Depression (Grant 23169, B.L.; Grant 21227, S.A.), the Louis Feil Trust (B.L.), the Stanley Family Foundation (B.L.), the Simons Foundation (Grant 344904, B.L.), the Human Frontier Science Program (Grant RGP0015/2016, B.L.), the Wodecroft Foundation (B.L.), the Cold Spring Harbor Laboratory (CSHL), and Northwell Health Affiliation (B.L.). This work was performed with assistance from CSHL Shared Resources, which are supported by Cancer Center Support Grant 5P30CA045508. We thank Dr. C. Lai (Indiana University, Bloomington, IN) for providing the ErbB4 ${ }^{\text {lox }}$ mice and for critically reading an earlier version of the manuscript, and Dr. P. Wulff (University of Kiel, Kiel, Germany) for providing the vector for making the AAV-CAG-DIO-TeLC-eGFP virus. We also thank members of the Li laboratory for helpful discussions.

Correspondence should be addressed to Bo Li, 1 Bungtown Road, Cold Spring Harbor, NY 11724. E-mail: bli@cshl.edu.

R. Paik's present address: Mouse Genome Engineering Facility, Department of Cellular and Integrative Physiology, UT-Health San Antonio, San Antonio, TX 78229. anxiety (the sustained emotional state induced by uncertain or diffuse threats), which manifest as distinct physiological and behavioral responses preparing us for either imminently or potentially harmful outcomes (Walker and Davis, 2008; Davis et al., 2010; Calhoon and Tye, 2015; Fox et al., 2015; Tovote et al., 2015; Shackman and Fox, 2016). Fear and anxiety, though distinct, come hand in hand, as anxiety almost always follows a fearful experience and can in turn influence fear responses to a threat. Moreover, exposures to acute and intense fearful experiences, especially those that are life threatening, often lead to maladaptive anxiety, or anxiety disorders, such as post-traumatic stress disorder (Etkin and Wager, 2007; Etkin, 2010; Fox and Kalin, 2014; McLaughlin et al., 2014; Fox et al., 2015). Despite intensive

H. Li's present address: Huazhong University of Science and Technology, Wuhan 430074, People's Republic of China

M.A. Penzo's present address: Unit on the Neurobiology of Affective Memory, National Institute of Mental Health, Bethesda, MD 20892.

DOI:10.1523/JNEUROSCI.0705-18.2018

Copyright $\odot 2018$ the authors $\quad 0270-6474 / 18 / 385567-17 \$ 15.00 / 0$ 
study, the neural mechanisms underlying anxiety, in particular maladaptive anxiety, remain incompletely understood.

Previous studies have identified that the central extended amygdala, in which the key components include the central amygdala (CeA) and the bed nucleus of the stria terminalis (BNST; Alheid and Heimer, 1988), has central roles in the generation of fear and anxiety states (Walker and Davis, 2008; Davis et al., 2010; Calhoon and Tye, 2015; Fox et al., 2015; Tovote et al., 2015; Gungor and Paré, 2016; Shackman and Fox, 2016). While an early model proposes that the CeA and the BNST have separate functions, such that the former controls fear and the latter is responsible for anxiety (Walker and Davis, 2008), more recent studies in humans and nonhuman primates (Etkin and Wager, 2007; Wager et al., 2008; Mobbs et al., 2010; Fox and Kalin, 2014; Andreatta et al., 2015; Fox et al., 2015) and rodents (Gungor and Paré, 2016) show that both structures are activated by explicit as well as potential threats. Thus, these studies suggest that the CeA and the BNST coordinate to orchestrate both acute and chronic responses to various kinds of threatening stimuli.

Both the CeA and the BNST are complex structures that contain heterogeneous neuronal populations, which likely form discrete neural circuits subserving distinct functions (Duvarci and Pare, 2014; Herry and Johansen, 2014; Stamatakis et al., 2014; Kash et al., 2015; Gungor and Paré, 2016). For instance, it has been shown that the somatostatin-expressing $\left(\mathrm{SOM}^{+}\right)$neurons in the lateral division of the $\mathrm{CeA}(\mathrm{CeL})$ undergo fear conditioninginduced synaptic strengthening that is required for fear memory formation (Li et al., 2013; Penzo et al., 2014, 2015). Furthermore, these neurons acquire responsiveness to threat-predicting sensory cues after conditioning (Li et al., 2013; Penzo et al., 2014, 2015; Yu et al., 2016; Fadok et al., 2017). Neurons in the oval nucleus (ov) of the BNST (ovBNST) and other subregions of the $\mathrm{BNST}$, on the other hand, are sufficient to induce anxiety-related behaviors (Jennings et al., 2013; Kim et al., 2013; Marcinkiewcz et al., 2016). Interestingly, the CeL sends strong and direct projections to the BNST (Davis et al., 2010; Oler et al., 2017), providing an anatomical basis for coordination between the two central extended amygdala nuclei in regulating anxiety.

In this study, we aimed at determining how the CeL and the BNST interact to participate in the generation of behavioral responses to anxiety. For this purpose, we took advantage of the mice showing heightened anxiety caused by selective deletion of Erbb4-a gene encoding a receptor tyrosine kinase that has important roles in multiple biological processes, including neurodevelopment, neuronal excitability, and synaptic function (Mei and Xiong, 2008; Mei and Nave, 2014) - in SOM ${ }^{+}$neurons (Ahrens et al., 2015). By using a combination of genetic, molecular, electrophysiological, pharmacological, and optogenetic methods, we discovered in the Erbb4 mutant mice that aberrantly potentiated excitatory synaptic drive onto $\mathrm{SOM}^{+} \mathrm{CeL}$ neurons promotes, through a disinhibitory mechanism, the activity of $\mathrm{SOM}^{+}$neurons in the dorsal BNST that in turn drive excessive anxiety. We further provided evidence that similar circuit and cellular processes are also engaged in maladaptive anxiety induced by stress in wild-type mice.

\section{Materials and Methods}

Animals. Before surgery, mice were housed under a $12 \mathrm{~h}$ light/dark cycle (7:00 A.M. to 7:00 P.M. light) in groups of two to five animals with food and water available ad libitum. Animals with implants were housed singly. All behavioral experiments were performed in the light cycle. The Som-cre (Taniguchi et al., 2011), Som-Flp (Penzo et al., 2015), Ai14 (Madisen et al., 2010), ErbB4 $4^{\text {flox }}$ (Golub et al., 2004), Gabrg2 ${ }^{\text {flox }}$ (Wulff et al.,
2007), and Rpl22 ${ }^{H A}$ (Sanz et al., 2009) mice were all described previously. The Som-Cre mice (RRID:IMSR_JAX:018973) and Som-Flp mice (RRID: IMSR_JAX:031629) were provided by Dr. Z. Josh Huang (Indiana University, Bloomington, IL), the ErbB $4^{\text {flox }}$ mice were provided by Dr. Cary Lai (Cold Spring Harbor Laboratory, Cold Spring Harbor, NY). The Ai14 reporter mice (stock \#007914; RRID:IMSR_JAX:007914), the Gabrg2 $2^{\text {flox }}$

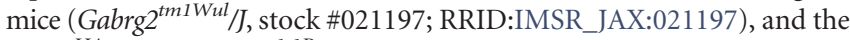
Rpl22 $2^{\text {HA }}$ mice (Rpl22 $2^{\text {tm 1.1Psam }}$, stock \#011029; RRID:IMSR_JAX:011029) were purchased from The Jackson Laboratory.

To generate the Rosa26-stop ${ }^{\text {flox }}$-GluA2 $2^{m u t}$ mouse line that conditionally expresses $G l u A 2^{m u t}$, the ZsGreen gene in Ai6 targeting vector (Madisen et al., 2010) was replaced with the GluA2 ${ }^{m u t}$ gene. The Ai6 vector was a gift from Dr. Hongkui Zeng from Allen Institute for Brain Science (Seattle, WA). C57BL/6 ES cells were transfected with the targeting vector and screened using the same strategy as that for Ai6 mice. Positive ES cell clones were used for tetroploid complementation to obtain male heterozygous mice following standard procedures (He et al., 2012). The GluA2 ${ }^{\text {mut }}$ contains two point mutations, the L483Y that impairs AMPA receptor desensitization (Weston et al., 2006; Christie et al., 2010) and the R845A that blocks AMPA receptor endocytosis (Hsieh et al., 2006), which were created based on the GluA2 cDNA using standard mutagenesis methods (Hsieh et al., 2006; Kopec et al., 2006).

All mice were bred onto a C57BL/6J background. Mice that were 2-4 months of age were used for all the behavioral and RNA sequencing (RNA-seq) experiments, and those that were 6-10 weeks of age were used for all the electrophysiological recordings in acute slices. Both male and female mice were used in most experiments in which the data were pooled because no sex difference was observed. All subjects were randomly allocated to the different experimental conditions used in this study. All procedures were approved by the Institutional Animal Care and Use Committee of Cold Spring Harbor Laboratory and conducted in accordance with the US National Institutes of Health (NIH) guidelines.

Viral vectors. The AAV2/9-Ef1a-DIO-hChR2(H134R)-eYFP, AAV2/ 9-CAG-DIO-GluA4-c-tail-GFP (Ahrens et al., 2015), AAV9-CAGfDIO-Cre-GFP (Penzo et al., 2015), AAV2/8-Ef1a-fDIO-mCherry and AAV2/9-CAG-DIO-ErbB4-T2A-GFP (which expresses the human ErbB4 CYT-2 isoform in a Cre-dependent manner) were produced by the University of North Carolina Vector Core Facility (Chapel Hill, NC). The AAV2/9-CAG-DIO-TeLC-eGFP (Murray et al., 2011) and AAV2/9Efla-DIO-GFP were made by the Penn Vector Core (Philadelphia, PA). All viral vectors were aliquoted and stored at $-80^{\circ} \mathrm{C}$ until use.

Stereotaxic surgery. Mice were anesthetized with ketamine $(100 \mathrm{mg} / \mathrm{kg}$ of body weight) supplemented with xylazine $(10 \mathrm{mg} / \mathrm{kg})$ and positioned in a stereotaxic injection frame (myNeuroLab, Leica Biosystems). A digital mouse brain atlas was linked to the injection frame to guide the identification and targeting of different brain areas (Angle Two Stereotaxic System, myNeuroLab, Leica Biosystems). Viruses were delivered with a glass micropipette (tip diameter, $\sim 5 \mu \mathrm{m}$ ) through a skull window (1-2 $\mathrm{mm}^{2}$ ) by pressure application (5-12 psi, controlled by a Picrospritzer III, General Valve). The injections were performed using the following stereotaxic coordinates: for the CeL, $-1.22 \mathrm{~mm}$ from bregma, $2.75 \mathrm{~mm}$ lateral from the midline, and $4.6 \mathrm{~mm}$ vertical from skull surface; for the ovBNST, $+0.20 \mathrm{~mm}$ from bregma, $1.00 \mathrm{~mm}$ lateral from the midline, and $4.00 \mathrm{~mm}$ vertical from skull surface. For all the manipulations in the BNST, we aimed at targeting the ov. However, due to the fact that the ovBNST is small and very close to the adjacent nuclei, our manipulations may have also affected the adjacent BNST nuclei, in particular the anteromedial (am) and anterolateral (al) areas.

During the surgical procedure, mice were kept on a heating pad maintained at $35^{\circ} \mathrm{C}$ and were brought back to their home cage for postsurgery recovery and monitoring. Postoperative care included intraperitoneal injection with $0.3-0.5 \mathrm{ml}$ of Lactated Ringer's solution and Metacam (1-2 mg/kg meloxicam; Boehringer Ingelheim Vetmedica) for analgesia and anti-inflammatory purposes. All adeno-associated virus (AAVs) were injected at a total volume of $\sim 0.3 \mu \mathrm{l}$ (ovBNST) or $0.5 \mu \mathrm{l}(\mathrm{CeL})$ and were allowed at least 4 weeks for maximal expression.

For in vivo pharmacological manipulations, mice were bilaterally implanted with stainless steel guide cannulae (26 gauge, $8.00 \mathrm{~mm}$; part C315G/SPC, Plastics One) above the left and right ovBNST, $0.5 \mathrm{~mm}$ 
dorsal to the site of virus injection. The left cannula was implanted in a $12^{\circ}$ angle. The cannulae were fixed to the skull with adhesive C\&B Metabond cement and acrylic dental cement. A metal head bar was also implanted posterior to the cannulae to facilitate restraining mice during the infusion procedure. Following surgery, a dummy cannula (part \#C315DC/SPC, Plastics One) was inserted into each guide cannula to seal off the opening. Mice were allowed to recover from surgery for a minimum of 2 weeks before behavioral testing.

Immunohistochemistry. Immunohistochemistry experiments were performed following standard procedures. Briefly, mice were anesthetized with Euthasol (0.4 ml; Virbac) and transcardially perfused with 40 $\mathrm{ml}$ of PBS, followed by $40 \mathrm{ml}$ of $4 \%$ paraformaldehyde (PFA) in PBS. Brains were removed immediately from the skull and placed in 4\% PFA for $24 \mathrm{~h}$ and then in $30 \%$ sucrose in PBS solution for at least $48 \mathrm{~h}$ at $4^{\circ} \mathrm{C}$. Coronal sections $(40-50 \mu \mathrm{m})$ were cut using a freezing microtome (catalog \#SM 2010R, Leica). For c-Fos labeling, sections were first washed in PBS $(3 \times 5 \mathrm{~min})$ and then blocked in $5 \%$ normal goat serum in PBST (0.3\% Triton X-100 in PBS) for $60 \mathrm{~min}$ at room temperature (RT) followed by incubation with primary antibodies overnight at $4^{\circ} \mathrm{C}$. Sections were washed with PBS $(5 \times 15 \mathrm{~min})$ and incubated with fluorescent secondary antibodies at RT for $1 \mathrm{~h}$. After washing with PBST $(5 \times 15$ $\min$ ), sections were mounted onto slides with Fluoromount-G (eBioscience). Images were taken using a LSM 710 Laser-Scanning Confocal Microscope (Carl Zeiss). The primary antibody used was anti-c-Fos (rabbit; 1:5000; catalog \#sc-52, Santa Cruz Biotechnology; RRID: AB_2106783). The fluorophore-conjugated secondary antibody used was Alexa Fluor 633 goat anti-rabbit IgG (H+L; catalog \#A21070, Life Technologies; RRID:AB_2535731). c-Fos-positive cells were counted manually using ImageJ software (NIH; RRID:SCR_003070).

In situ hybridization. We performed in situ hybridization (ISH) using RNA probes to detect the expression of Erbb4 and Prodynorphin (Pdyn) mRNA in the CeL. The probes used to detect $P d y n$ mRNA are the same as those used by the Allen Mouse Brain Atlas (Allen Institute for Brain Science; RRID:SCR_002978; Lein et al., 2007). We prepared an antisense probe corresponding to the 5-891 bp of Erbb4 mRNA (NCBI Gene accession \#NM_010154.2). Mice were transcardially perfused as described above. Brains were dissected out and postfixed overnight then cryoprotected in 30\% sucrose before being embedded in Tissue-Tek O.C.T. Compound (Sakura Finetek) and stored at $-80^{\circ} \mathrm{C}$. Before the experiment, coronal brain sections $(60 \mu \mathrm{m})$ were cryosectioned and collected on one set of slides, on which the sections were immediately fixed in $4 \%$ paraformaldehyde, rinsed, and treated with proteinase $\mathrm{K}(10 \mu \mathrm{g} /$ ml; Roche; RRID:AB_2313640). Subsequently, the sections were acetylated, permeabilized, and equilibrated in hybridization solution for 2-4 $\mathrm{h}$ at $65^{\circ} \mathrm{C}$. The sections were then incubated for $14-18 \mathrm{~h}$ at $65^{\circ} \mathrm{C}$ in fresh hybridization buffer containing RNA probes $(0.3 \mu \mathrm{g} / \mathrm{ml})$. The sections were washed in high-stringency buffers, followed by incubation in a buffer containing alkaline phosphatase-conjugated sheep anti-digoxigenin antibody (1:1000; Roche) at $4^{\circ} \mathrm{C}$ for $12-18 \mathrm{~h}$. After extensive washing, the sections were incubated in staining solution containing nitro blue tetrazolium and 5-bromo-4-chloro-3-indolyl-phosphate (Roche) at $37^{\circ} \mathrm{C}$ for $2.5 \mathrm{~h}$ (Pdyn) or overnight (Erbb4). The sections were subsequently washed, fixed in $4 \%$ PFA, and coverslipped.

ISH-processed sections were imaged with a Zeiss Observer inverted microscope at $5 \times$ magnification under bright-field illumination. Brain sections spanning the entire anteroposterior extent of the CeL were imaged. We used Fiji software (NIH; RRID:SCR_002285) for image analysis. Standardized masks were used to outline the region of interest (ROI) as well as a background region for each image. To calculate the mean intensity of each ROI, we first inverted the color of each image, and then subtracted the mean intensity value of the background region from the ROI. The average intensity for each section was then summed to obtain the total intensity for the CeL.

Open field test. Open field test (OFT) was performed in a nontransparent square box $42.5 \times 42.5 \times 40 \mathrm{~cm}$. The arena was enclosed in a soundattenuating chamber with a house light on the ceiling. Animals were placed in one of the corners of the open field arena at the start of a session. The center zone was set to $21 \times 21 \mathrm{~cm}$ in the middle of the arena. Mice were allowed to explore the arena for $15 \mathrm{~min}$, while their behavior was videotaped using a monochrome CCD camera (catalog \#WV-BP334, Panasonic) at $4 \mathrm{~Hz}$. The resulting data were stored on a personal computer and analyzed using the imaging-processing and tracking software Ethovision XT 5.1 (Noldus Information Technologies; RRID: SCR_000441). Parameters assessed were the total distance traveled, time spent in the center zone, the number of entries to the center zone, and latency to first enter the center zone. The arena was thoroughly cleaned with $70 \%$ ethanol in between subjects.

Elevated plus maze test. The apparatus for the elevated plus maze test (EPMT) was constructed from white Plexiglas and consisted of two open arms without walls ( $30 \mathrm{~cm}$ long and $5 \mathrm{~cm}$ wide) and two arms enclosed by 15.25-cm-high nontransparent walls. The arms were extended from a central platform $(5 \times 5 \mathrm{~cm})$ and were arranged such that the identical arms were opposite to each other. The maze was raised to a height of 50 $\mathrm{cm}$ above the floor. At the start of the session, animals were placed in the center zone, with their heads oriented to a closed arm. Mice were allowed to explore the maze for $10 \mathrm{~min}$ while their behavior was videotaped using a monochrome CCD camera (catalog \#WV-BP334, Panasonic) at $4 \mathrm{~Hz}$. The resulting data were stored on a personal computer and analyzed using Ethovision XT 5.1 (Noldus Information Technologies; RRID: SCR_000441). The parameters assessed were total distance traveled, time spent in the open arms, number of entries to the open arms, latency to the first entry into an open arm, time spent in the closed arms, number of entries into the closed arms, and time spent in the center. The maze was thoroughly cleaned with $70 \%$ ethanol in between subjects.

In the case that the same mice were used for OFT and EPMT, the order of behavioral tests was always OFT and EPMT.

Norbinaltorphimine infusion. Mice were briefly head restrained using the implanted head bar, while the dummy cannulae were removed and an injection cannula (33 gauge, $8.5 \mathrm{~mm}$; part \#C3151, Plastics One) was inserted into each of the guide cannulae. The injection cannulae were designed to protrude $0.5 \mathrm{~mm}$ from the tip of the guide cannulae and thus penetrate into the ovBNST. A dose of $2 \mu \mathrm{g}$ norbinaltorphimine (norBNI; or $0.9 \%$ sodium chloride as a control) was slowly infused bilaterally into ovBNT at a flow rate of $50 \mathrm{nl} / \mathrm{min}$ and in a total volume of $0.3 \mu \mathrm{l} /$ infusion site. Following infusion, the injection cannulae were left in place for 5 min to allow the solution to diffuse from the cannulae tips. The dummy cannulae were subsequently reinserted into the guide cannulae, and mice were returned to their home cage. Behavioral testing for anxiety was performed $16 \mathrm{~h}$ after infusion.

The stress procedure. We modified a previously established procedure to stress the mice (Wang et al., 2014; Perova et al., 2015). Briefly, mice were exposed to a session of 360 inescapable, uncontrollable electric footshocks over a 60 min period. The shock intensity was set at $0.3 \mathrm{~mA}$, the duration of each shock was randomized between 1 and $3 \mathrm{~s}$, and the intershock intervals were randomized between 1 and $15 \mathrm{~s}$. Control mice were handled similarly except that they were not shocked. Twenty-four hours later, these mice were tested in the EPMT, followed by being subjected to acute slice preparation for electrophysiological recording.

Electrophysiology. Mice used for electrophysiological experiments were anesthetized with isoflurane, decapitated before their brains were quickly removed and chilled in ice-cold dissection buffer $(110.0 \mathrm{~mm}$ choline chloride, $25.0 \mathrm{~mm} \mathrm{NaHCO}, 1.25 \mathrm{~mm} \mathrm{NaH}_{2} \mathrm{PO}_{4}, 2.5 \mathrm{~mm} \mathrm{KCl}, 0.5 \mathrm{~mm}$ $\mathrm{CaCl}_{2}, 7.0 \mathrm{mM} \mathrm{MgCl}_{2}, 25.0 \mathrm{~mm}$ glucose, $11.6 \mathrm{~mm}$ ascorbic acid, and 3.1 $\mathrm{mm}$ pyruvic acid, and gassed with $95 \% \mathrm{O}_{2}$ and $5 \% \mathrm{CO}_{2}$ ). Coronal slices $(300 \mu \mathrm{m})$ containing the amygdala complex or ovBNST were cut in the dissection buffer using an HM650 Vibrating-blade Microtome (Thermo Fisher Scientific) and were subsequently transferred to a storage chamber containing artificial CSF (ACSF; $118 \mathrm{~mm} \mathrm{NaCl}, 2.5 \mathrm{~mm} \mathrm{KCl,} 26.2 \mathrm{~mm}$ $\mathrm{NaHCO}_{3}, 1 \mathrm{~mm} \mathrm{NaH}_{2} \mathrm{PO}_{4}, 20 \mathrm{~mm}$ glucose, $2 \mathrm{~mm} \mathrm{MgCl}_{2}$, and $2 \mathrm{~mm} \mathrm{CaCl}_{2}$, at $34^{\circ} \mathrm{C}, \mathrm{pH} 7.4$, gassed with $95 \% \mathrm{O}_{2}$ and $5 \% \mathrm{CO}_{2}$ ). After at least $60 \mathrm{~min}$ of recovery time, slices were transferred to RT $\left(20-24^{\circ} \mathrm{C}\right)$ conditions and were constantly perfused with ACSF.

A visually guided whole-cell patch-clamp recording was obtained with Multiclamp 700B amplifiers and pCLAMP 10 software (Molecular Devices; RRID:SCR_011323), and was guided using an Olympus BX51 Microscope equipped with both transmitted and epifluorescence light sources (Olympus). $\mathrm{SOM}^{+}$cells were identified based on their fluorescence (tdTomato). Evoked synaptic responses from $\mathrm{SOM}^{+} / \mathrm{SOM}^{-}$neu- 
ronal pairs in the ovBNST were obtained by electrical stimulation with a bipolar stimulating electrode placed within the ovBNST $\sim 0.2 \mathrm{~mm}$ away from the recorded cell bodies. Electrical stimulation was delivered every $10 \mathrm{~s}$. Synaptic responses were low-pass filtered at $1 \mathrm{kHz}$ and recorded at holding potentials of $-70 \mathrm{mV}$ (for AMPA receptor-mediated responses), $+40 \mathrm{mV}$ (for NMDA receptor-mediated responses), or $0 \mathrm{mV}$ (for $\mathrm{GABA}_{\mathrm{A}}$ receptor-mediated responses). NMDA receptor-mediated responses were quantified as a mean current amplitude between 50 and 60 ms after the onset of stimulation. Recordings were made in the ACSF. The internal solution for voltage-clamp experiments contained $115 \mathrm{~mm}$ cesium methanesulphonate, $20 \mathrm{~mm} \mathrm{CsCl,} 10 \mathrm{~mm}$ HEPES, $2.5 \mathrm{~mm} \mathrm{MgCl}$, $4 \mathrm{mM} \mathrm{Na}_{2}$-ATP, $0.4 \mathrm{~mm} \mathrm{Na}_{3} \mathrm{GTP}, 10 \mathrm{~mm} \mathrm{Na}$-phosphocreatine, and 0.6 mM EGTA, pH 7.2. Evoked EPSCs were recorded with picrotoxin (100 $\mu \mathrm{M})$ added to the ACSF. Evoked IPSCs were recorded in the presence of AP-5 $(100 \mu \mathrm{M})$ and CNQX $(5 \mu \mathrm{M})$. Miniature EPSCs (mEPSCs) were recorded in the presence of tetrodotoxin $(1 \mu \mathrm{M})$ and picrotoxin $(100$ $\mu \mathrm{M})$. Spontaneous IPSCs (sIPSCs) were recorded in the presence of AP-5 and CNQX. mEPSCs and sIPSCs were analyzed using Mini Analysis software (Synaptosoft; RRID:SCR_002184). The norBNI (used at 100 $\mathrm{nM}$ ) were purchased from Sigma-Aldrich.

To evoke IPSCs in ovBNST neurons driven by the inputs from $\mathrm{SOM}^{+}$ CeL neurons, the AAV-DIO-ChR2(H134R)-YFP was injected into the $\mathrm{CeL}$ of Som-Cre;Ai14 mice and allowed to express for 2-3 weeks. Acute brain slices were prepared, and a blue light was used to stimulate channelrhodopsin 2 (ChR2)-expressing axons. The light source was a singlewavelength LED system $(\lambda=470 \mathrm{~nm}$; CoolLED) connected to the epifluorescence port of the Olympus BX51 microscope. Light pulses of $0.5 \mathrm{~ms}$, triggered by a through the lens signal from the Clampex software, were delivered to evoke synaptic responses.

$R N A-S e q$. Mice were deeply anesthetized and rapidly decapitated. Brains were dissected and sectioned at $500 \mu \mathrm{m}$ on ice in a stainless steel brain matrix (EMS 69090-C). The CeL was microdissected in ice-cold PBS under a stereomicroscope and stored at $-80^{\circ} \mathrm{C}$. Tissue from $8-12$ mice were pooled for each sample. Tissue homogenization, immunoprecipitation of polysomes from $\mathrm{SOM}^{+}$neurons, and mRNA extraction were performed as previously described (Sanz et al., 2009; Heiman et al., 2014). Libraries were prepared from 4 input and 10 immunoprecipitated (IP) samples using NuGEN Ovation RNA-Seq Kits (7102 and 0344). Multiplexed libraries were sequenced with $76 \mathrm{bp}$ single end runs on the Illumina platform. Reads were adapter trimmed and quality filtered at $\mathrm{Q}>30$ using an internal Fast-X toolkit [http://hannonlab.cshl.edu/ fastx_toolkit/ (Galaxy version 1.0.1); RRID:SCR_005534]. Filtered reads were then mapped to the mm10 reference genome using STAR (RRID: SCR_015899; Galaxy version 0.0.1; Dobin et al., 2013; Yue et al., 2014). An average of 32 million reads were uniquely mapped per sample. The number of reads mapped to each gene was calculated using featureCounts (RRID:SCR_012919; Galaxy version 2.4.5-p1; Liao et al., 2014), and differential expression between IP and input samples was determined using DESeq2 with an FDR of 0.1 (RRID:SCR_015687; Galaxy Version 1.0.0; Love et al., 2014). Normalized expression values, $\log _{2}$ fold change values, and $p$ values (Benjamini-Hochberg adjusted) were obtained from DESeq2 to generate heatmap and volcano plots using ggplot in R (RRID:SCR_014601 and RRID:SCR_001905). All data files have been deposited in the Gene Expression Omnibus (accession GSE113979; RRID:SCR_007303).

Experimental design and statistical analysis. Statistical analyses were performed with GraphPad Prism 7 Software (GraphPad Software; RRID: SCR_002798). The sample size was estimated using power analysis based on our preliminary studies. Normality was tested by the D'AgostinoPearson or Shapiro-Wilk normality test. Data from two conditions were compared using two-tailed unpaired Student's $t$ tests. Multiple-condition comparisons were performed using ANOVA with post hoc tests as described in Results. $p$ values were considered significant if $<0.05$. Quantitative data are presented as mean \pm SEM.

Behavioral tests were performed by an investigator with knowledge of the identities of the experimental groups. All behavioral experiments were controlled by computer systems, with data collected and analyzed in an automated and unbiased way. Both male and female mice were used in this study. The behavioral data in Figures $1 a-d$ and $2, d$ and $e$, were obtained from male mice. The behavioral data in Figure 3, $d$ and $e$, were obtained from five male and three female mice (control) and four male and two female mice ( $\left.\mathrm{CeL}^{\text {SOM_Erbb4-KO}}\right)$. The behavioral data in Figure $3, i$ and $j$, were obtained from four male and four female mice (control) and four male and four female mice ( $\left.\mathrm{CeL}^{\text {SOM_GluA2mut }}\right)$. The behavioral data in Figure 7, $b$ and $c$, were obtained from four male and four female mice (KO_GFP) and four male and four female mice (KO_TeLC). The behavioral data in Figure 7, $e$ and $f$, were obtained from four male and five female mice ( $\boldsymbol{\gamma} 2-\mathrm{WT})$ and four male and six female mice $(\boldsymbol{\gamma} 2-\mathrm{KO})$. The behavioral data in Figure $8 i$ were obtained from seven male and five female $\mathrm{KO}$ mice (saline), four male and two female KO mice (norBNI), three male and two female WT mice (saline), and two male and three female WT mice (norBNI). The behavioral data in Figure $9 a$ were obtained from eight male and four female mice (control) and seven male and five female mice (shock).

For the quantification of c-Fos (Fig. 4), male mice were used; six slices spanning the CeL and three slices spanning the oval nucleus of the BNST in each of the two hemispheres of each brain were used for quantification. Electrophysiology experiments were conducted on male and female mice, with balanced sexes allocated to each of the groups.

\section{Results}

\section{Deletion of ErbB4 from SOM ${ }^{+}$cells promotes anxiety and affects CeL function}

In the cortex, BLA, and hippocampus, ErbB4 is highly expressed in parvalbumin-expressing (Vullhorst et al., 2009; Fazzari et al., 2010; Lu et al., 2014) and vasoactive intestinal polypeptideexpressing (Batista-Brito et al., 2017) GABAergic neurons. It has been shown that deletion of ErbB4 from these neurons impairs synaptic transmission and causes circuit and behavioral deficits (Lu et al., 2014; Batista-Brito et al., 2017). ErbB4 is also expressed in $\mathrm{SOM}^{+}$neurons in subcortical areas enriched with these neurons, including the thalamic reticular nucleus (TRN) and the CeL (Neddens and Buonanno, 2011; Ahrens et al., 2015; also see Allen Brain Atlas). To study how ErbB4 regulates circuit function in these subcortical structures, thereby affecting animal behavior, in a recent study we targeted ErbB4 selectively in $\mathrm{SOM}^{+}$neurons by breeding the Som-Cre;Erbb4 flox mice (Golub et al., 2004; Ahrens et al., 2015). This led to the generation of the Som ${ }^{\text {Erbb4 }+1-}[$ Erbb4 heterozygous deletion in $\mathrm{SOM}^{+}$cells (HET)] and Som ${ }^{\text {Erbb4-1- }}$ [Erbb4 homozygous deletion (knockout) in $\mathrm{SOM}^{+}$neurons (KO)] mice along with their Som ${ }^{\text {Erbb4 }+1+}[$ Erbb4 wild-type (WT)] littermates (Ahrens et al., 2015). In the same study, we found that the HET and KO mice show altered sensory processing and behavioral inflexibility, phenotypes that are caused by aberrantly enhanced excitatory synaptic transmission onto $\mathrm{SOM}^{+}$TRN neurons and the resulting TRN dysfunction (Ahrens et al., 2015). To further investigate the behavioral changes in these mice, we examined them and their WT littermates in the EPMT and OFT, two assays commonly used to assess anxiety in rodents (Belzung and Griebel, 2001; Blanchard et al., 2001). Interestingly, both the HET and the KO mice showed behavioral patterns indicative of elevated anxiety when compared with WT mice (Fig. 1a,b). For example, in the EPMT, the mutant mice showed reduced time spent on the open arms, reduced number of entries to the open arms, increased latency to entering the open arms, increased time in the closed arms, and reduced time in the center of the EPM (Fig. 1a: WT, $n=15$ mice; HET, $n=15$ mice; $\mathrm{KO}, n=17$ mice; from left to right: time exploring open arms: $F_{(2,44)}=22.67, p<0.0001$; WT vs HET, $p=0.0001$; WT vs KO, $p<0.0001$; number of entries into open arms: $F_{(2,44)}=12.17$, $p<0.0001$; WT vs HET, $p=0.0058$; WT vs KO, $p<0.0001$; latency to first entry into open arms: $F_{(2,44)}=3.68, p=0.033$; WT vs KO, $p=0.027$; time in closed arms: $F_{(2,44)}=22.8, p<0.0001$; WT vs HET, $p<0.0001$; WT vs KO, $p<0.0001$; number of 
a

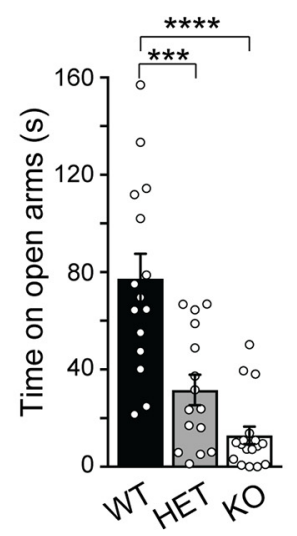

b

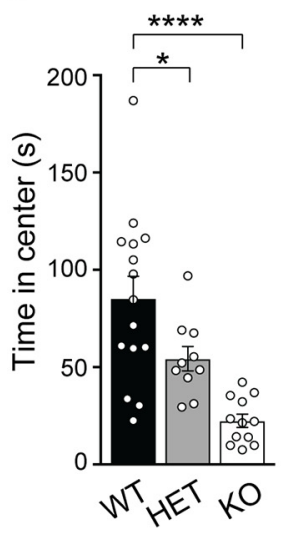

e

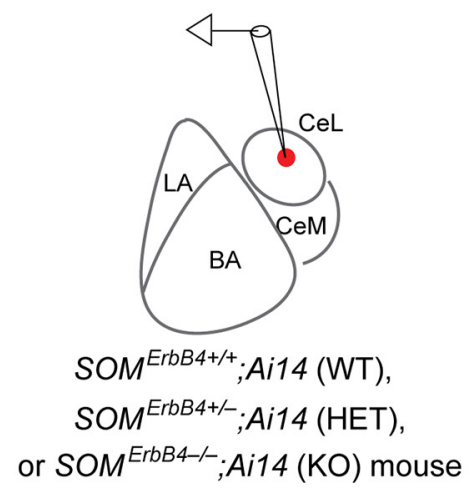

Elevated Plus Maze Test (EPMT)
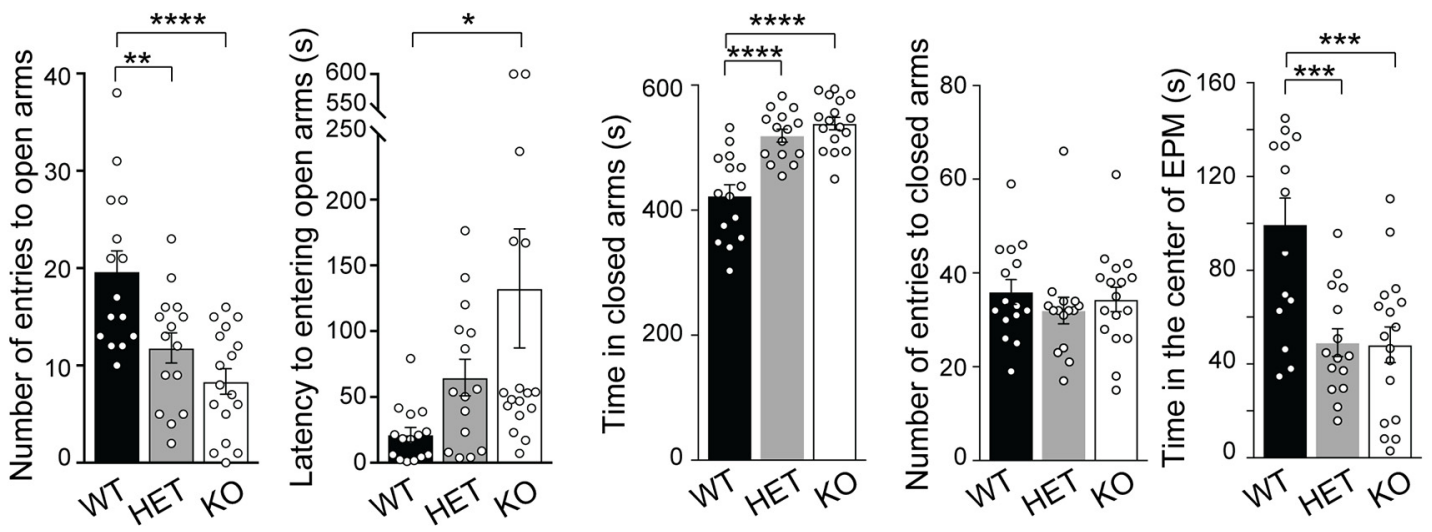

C
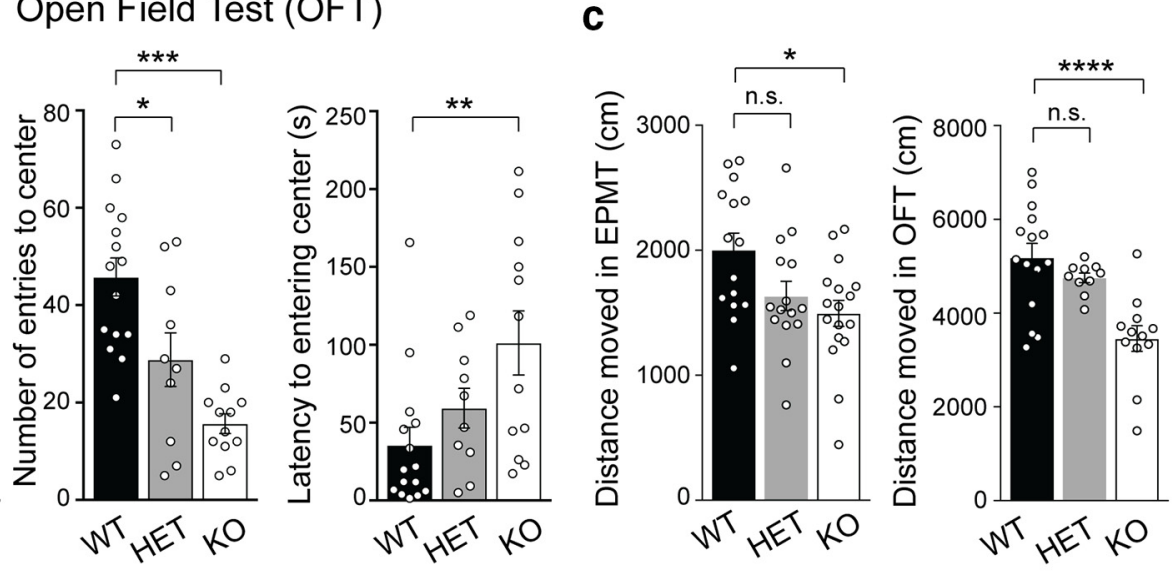

d

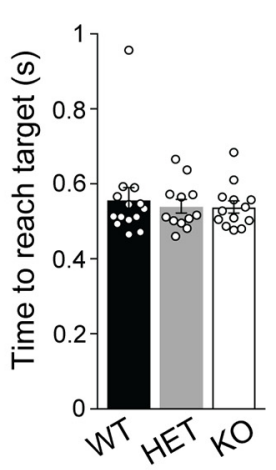

g

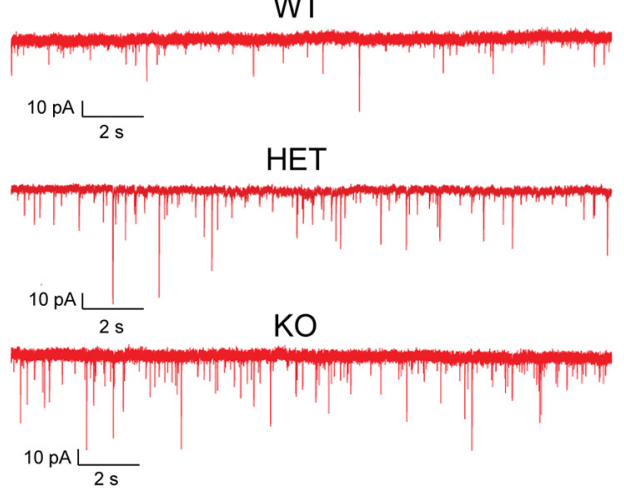

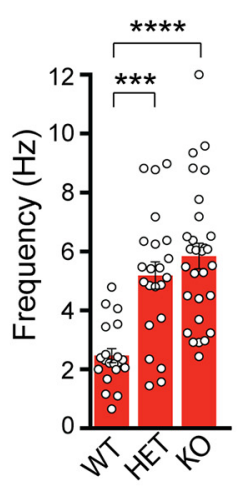

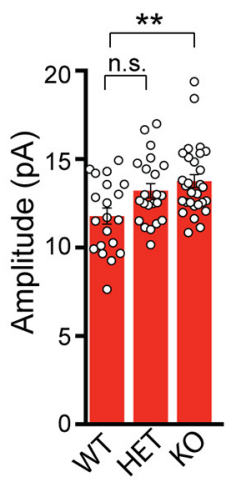

Figure 1. ErbB4 deficiency in $\mathrm{SOM}^{+}$neurons causes increased anxiety and enhanced excitatory synaptic transmission onto $\mathrm{SOM}^{+}$CeL neurons. $\boldsymbol{a}$, Quantification of behavioral parameters in the EPMT. $\boldsymbol{b}$, Quantification of behavioral parameters in the OFT. c, Distance moved in EPMT and OFT. $\boldsymbol{d}$, Time needed to reach targets in a decision-making task (Ahrens et al., 2015). $\boldsymbol{e}$, A schematic of the recording configuration. $\boldsymbol{f}$, Representative mEPSC traces recorded from SOM ${ }^{+}$neurons in the CeL of WT, HET and KO mice. $\boldsymbol{g}$, Left, Quantification of mEPSC frequency. Right, Quantification of mEPSC amplitude. Data are presented as the mean \pm SEM. ${ }^{*} p<0.05,{ }^{* *} p<0.01,{ }^{* * *} p<0.001,{ }^{* * * *} p<0.0001$, n.s. (not significant).

entries to closed arms: $F_{(2,44)}=0.5245, p=0.5958$; time in the center of EPM: $F_{(2,44)}=11.74, p<0.0001$; WT vs HET, $p=$ 0.0005 ; WT vs KO, $p=0.0003$; one-way ANOVA followed by Tukey's test); in the OFT, the mutant mice showed reduced time spent in the center, reduced number of entries to the center, and increased latency to entering the center (Fig. $1 b$ : WT, $n=15$ mice; HET, $n=12$ mice; KO, $n=10$ mice; left: time exploring center, $F_{(2,34)}=14.21 ; p<0.0001$; WT vs HET, $p=0.054$; WT vs $\mathrm{KO}, p<0.0001$; middle: number of entries into center, $F_{(2,34)}=$ $16.26, p<0.0001$; WT vs HET, $p=0.013$; WT vs KO, $p<0.0001$; right: latency to first entry into center, $F_{(2,34)}=5.01, p=0.012$; WT vs KO, $p=0.006$; one-way ANOVA followed by Tukey's test). The mutant mice showed a slight reduction in moving distance in the EPMT and OFT (Fig. $1 c$ : EPMT, $F_{(2,44)}=4.943, p=$ 0.012 ; WT vs KO, $p=0.01$; OFT, $F_{(2,34)}=11.98, p=0.0001$; WT vs $\mathrm{KO}, p<0.0001$; HET vs $\mathrm{KO}, p=0.007$; one-way ANOVA followed by Tukey's test), but this may reflect the fact that these mice were in a highly anxious state and thus reluctant to move, rather than reflecting a motor deficit. Consistent with this interpretation, in the recent study we did not observe any movement 


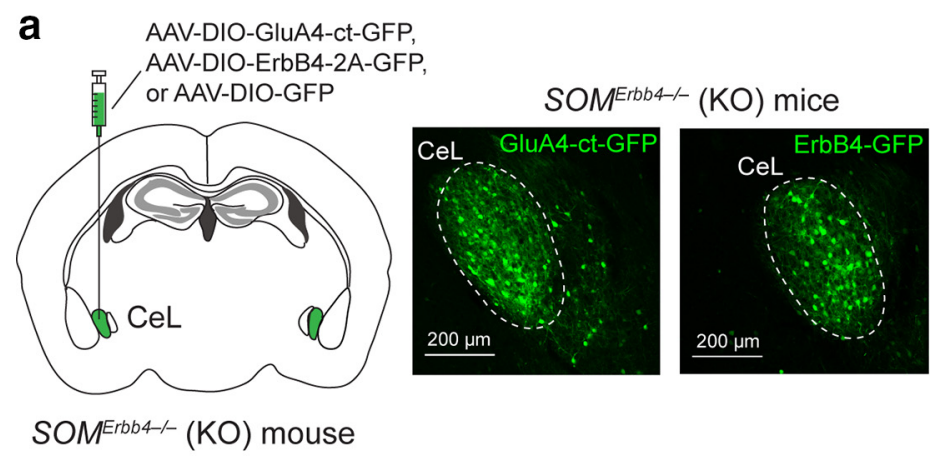

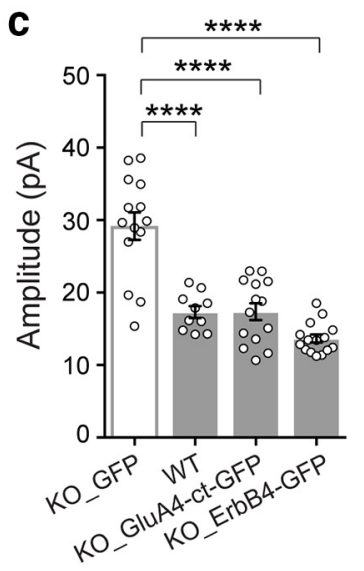

d

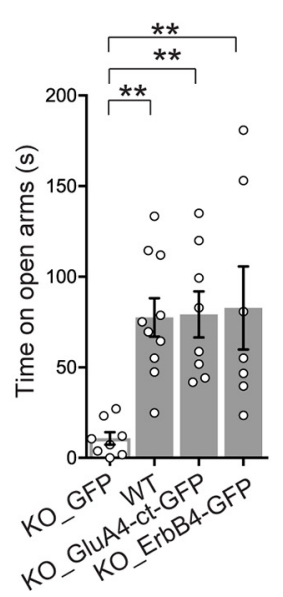

Elevated Plus Maze Test (EPMT)

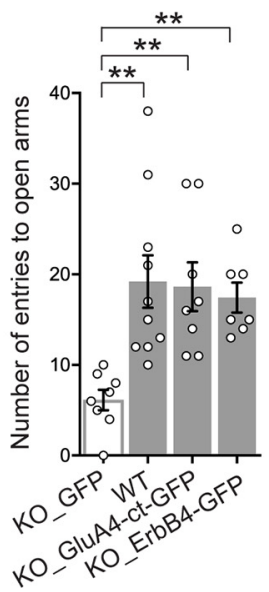

b

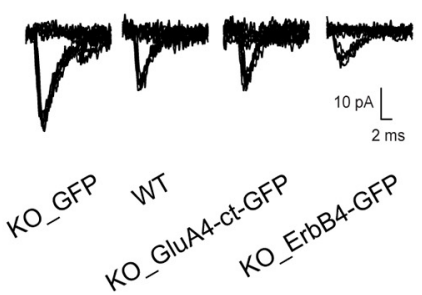

e

Open Field Test (OFT)

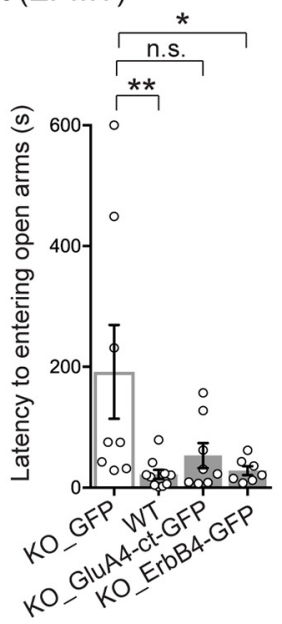

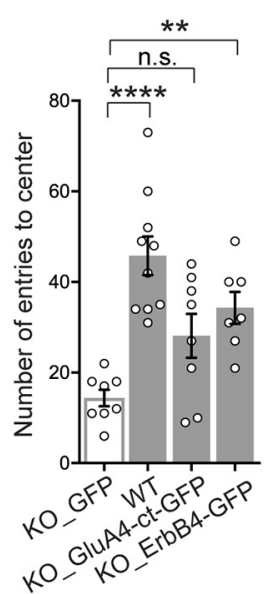

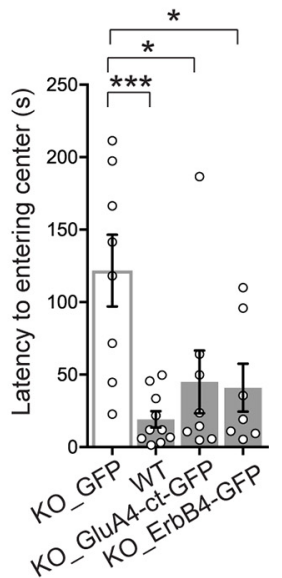

Figure 2. Rescue of behavioral phenotypes by rescuing the potentiated excitatory synaptic transmission onto SOM ${ }^{+}$CeL neurons in the ErbB4 mutant mice. $\boldsymbol{a}$, Left, A schematic of the experimental design. Right, Example images of the SOM ${ }^{+}$CeL neurons expressing GluA4-ct-GFP or ErbB4-2A-GFP. $\boldsymbol{b}$, Representative traces of EPSCs recorded from SOM ${ }^{+}$CeL neurons in response to minimal electrical stimulation in the LA (emEPSCs). c, Quantification of the amplitude of emEPSCs. $\boldsymbol{d}$, Quantification of behavioral parameters in the EPMT. $\boldsymbol{e}$, Quantification of behavioral parameters in the OFT. Data are presented as the mean \pm SEM. ${ }^{*} p<0.05,{ }^{* *} p<0.01,{ }^{* * *} p<0.001$, ${ }^{* * *} p<0.0001$, n.s. (not significant).

impairments in the mutant mice in decision-making tasks (Ahrens et al., 2015), wherein the mutant mice were as fast as the WT mice in traveling from a starting position to target positions to obtain rewards (Fig. $1 d ; F_{(2,37)}=0.874, p=0.829$, one-way ANOVA).

Because heterozygous or homozygous deletion of Erbb4 causes enhanced excitatory synaptic transmission onto $\mathrm{SOM}^{+}$ TRN neurons (Ahrens et al., 2015), we reasoned that the deletion of one or both copies of Erbb4 might also lead to aberrant potentiation of the excitatory synapses onto $\mathrm{SOM}^{+} \mathrm{CeL}$ neurons- the synapses that play an important role in fear processing ( $\mathrm{Li}$ et al., 2013; Penzo et al., 2015)—-thereby resulting in the heightened anxiety in the HET and KO mice. To test this hypothesis, we tagged $\mathrm{SOM}^{+}$neurons by breeding mice to incorporate the WT $\left(\right.$ Som $\left.^{\text {Erbb4+/+ }}\right)$, HET $\left(\right.$ Som $\left.^{\text {Erbb4+/- }}\right)$, or KO $\left(\right.$ Som $\left.^{\text {Erbb4-/- }}\right)$ alleles and the Ai14 reporter allele (Madisen et al., 2010), and recorded mEPSCs from SOM ${ }^{+}$(red fluorescent) neurons in the CeL in acute brain slices (Fig. $1 e-g$ ). We found that the frequency of the mEPSCs was markedly increased in the mutant mice relative to the WT mice (Fig. 1f,g). The amplitude of the mEPSCs was also increased in the KO mice, and had a tendency to increase in the HET mice [Fig. $1 f, g$; quantification of mEPSC frequency: WT, $n=20$ cells ( 5 mice); HET, $n=22$ cells ( 6 mice); KO, $n=30$ cells (6 mice), $F_{(2,69)}=15.71, p<0.0001$; WT vs HET, $p=0.0009$; WT vs KO, $p<0.0001$; one-way ANOVA followed by Tukey's test; quantification of mEPSC amplitude: WT, $n=20$ cells ( 5 mice); HET, $n=22$ cells $(6$ mice $)$; KO, $n=30$ cells $\left(6\right.$ mice); $F_{(2,69)}=$ $6.428, p=0.0028$; WT vs $\mathrm{KO}, p=0.0018$; one-way ANOVA followed by Tukey's test]. This result raises the possibility that the enhanced excitatory synaptic drive onto $\mathrm{SOM}^{+} \mathrm{CeL}$ neurons is responsible for the anxiety phenotypes of the mutant mice.

$\mathrm{SOM}^{+} \mathrm{CeL}$ neurons are both necessary and sufficient for the anxiety phenotypes in the mutant mice

To determine whether the enhanced excitatory synaptic transmission onto $\mathrm{SOM}^{+} \mathrm{CeL}$ neurons is causally related to the enhanced anxiety in the mutant mice, we first performed "rescue" experiments, in which we either reintroduced ErbB4, or delivered AMPAR subunit GluA4 C-terminal tail (GluA4-ct), a peptide that can weaken excitatory synaptic transmission (Zhu et al., 2000; Ahrens et al., 2015), into SOM ${ }^{+} \mathrm{CeL}_{\text {neurons in the mutant }}$ mice using Cre-dependent AAVs (Fig. 2a). Both molecules effectively normalized the enhanced excitatory synaptic transmission onto $\mathrm{SOM}^{+} \mathrm{CeL}$ neurons [Fig. $2 b, c$; KO_GFP, $n=14$ cells (3 mice); WT, $n=10$ cells ( 2 mice); KO_GluA4-ct-GFP, $n=14$ cells ( 3 mice); KO_ErbB4-GFP, $n=15$ cells $(3$ mice $) ; F_{(3,49)}=30.67$, $p<0.0001$; WT vs KO_GFP, $p<0.0001$, KO_GFP vs KO_GluA4-ct-GFP, $p<0.0001$, KO_GFP vs KO_ErbB4-GFP, $p<0.0001$; one-way ANOVA followed by Tukey's test] and, remarkably, also reversed the anxiety phenotypes of these mice 
a

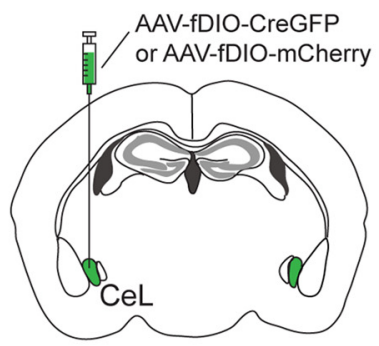

Som-Flp;Erbb4 $4^{\text {floxfliox }}$ mouse

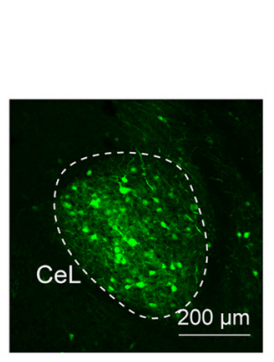

.

\section{$\frac{20 \mathrm{pA}}{2 \mathrm{~s}}$}

d

Elevated Plus Maze Test (EPMT)
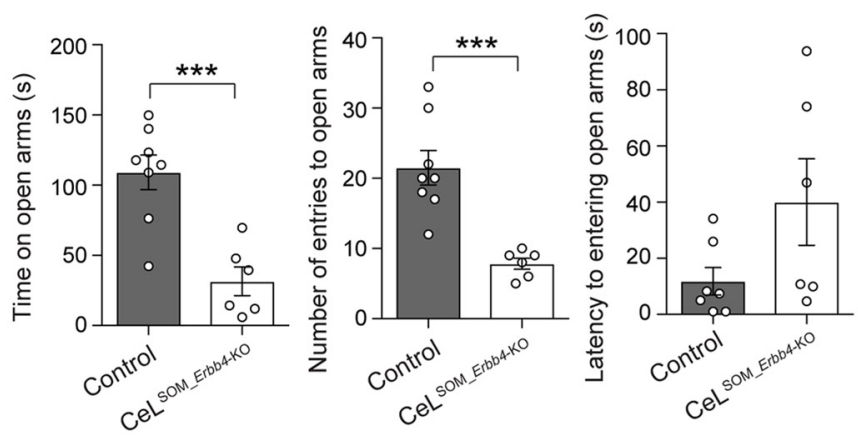

\section{f}

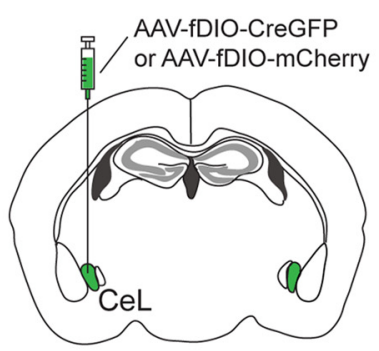

Som-Flp;Rosa26-

stop fiox-GluA2 ${ }^{\text {mut }}$ mouse

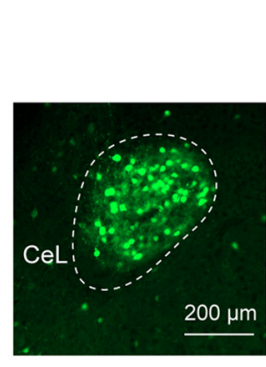

g b

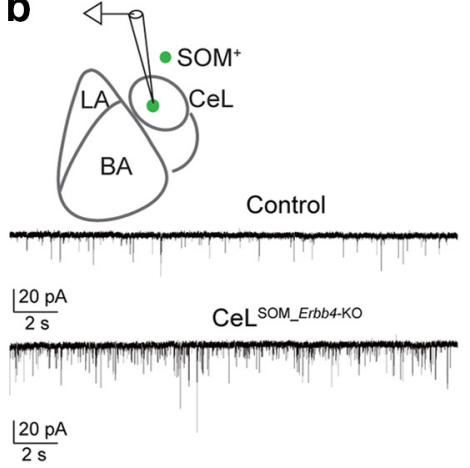

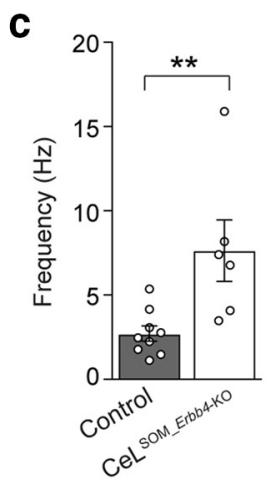

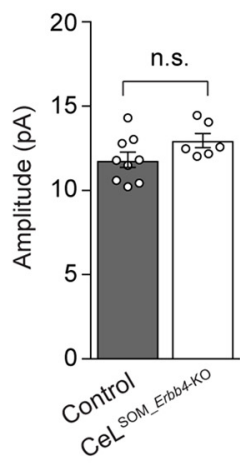

e

Open Field Test (OFT)
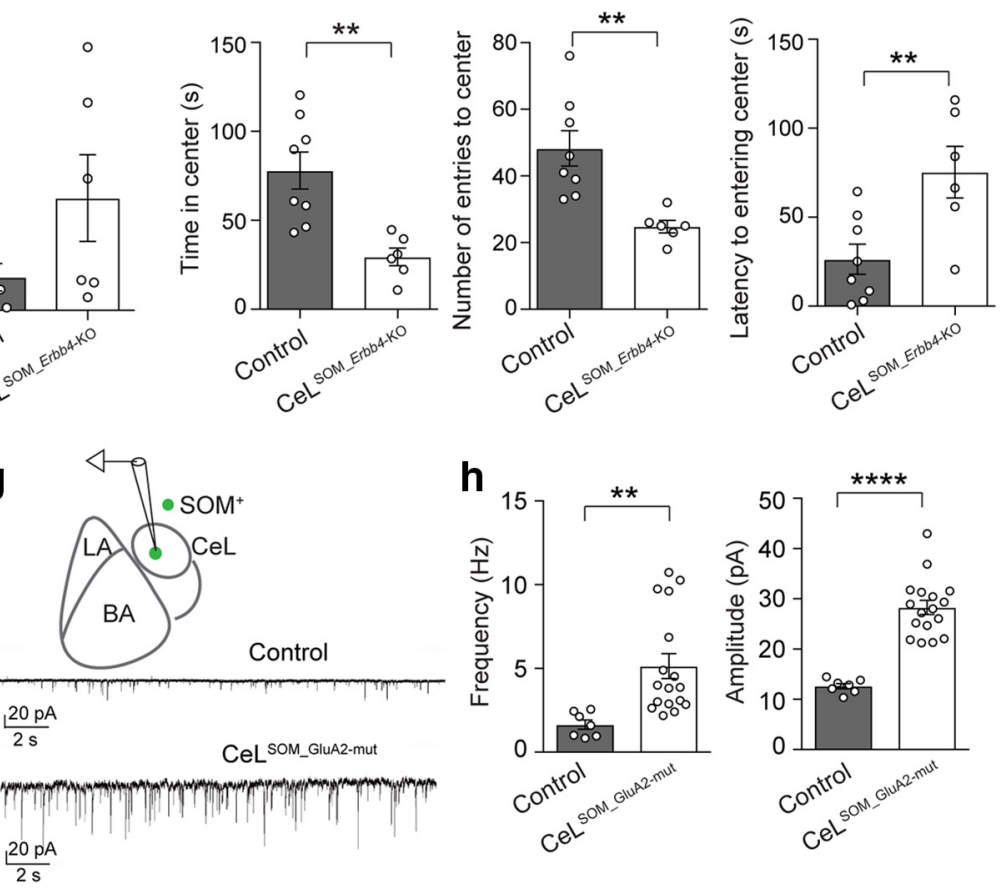

i

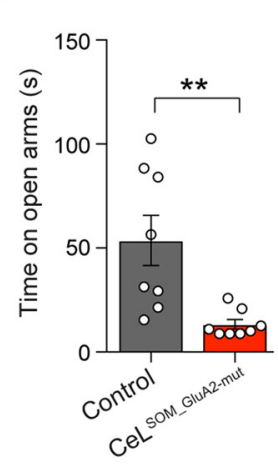

Elevated Plus Maze Test (EPMT)

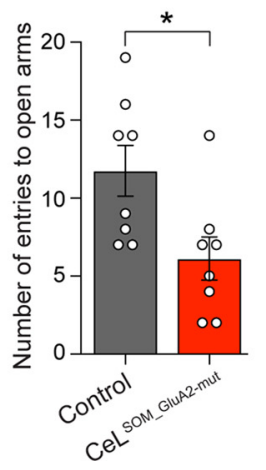

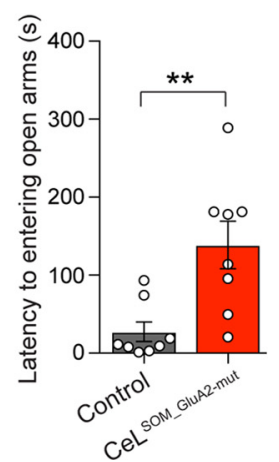
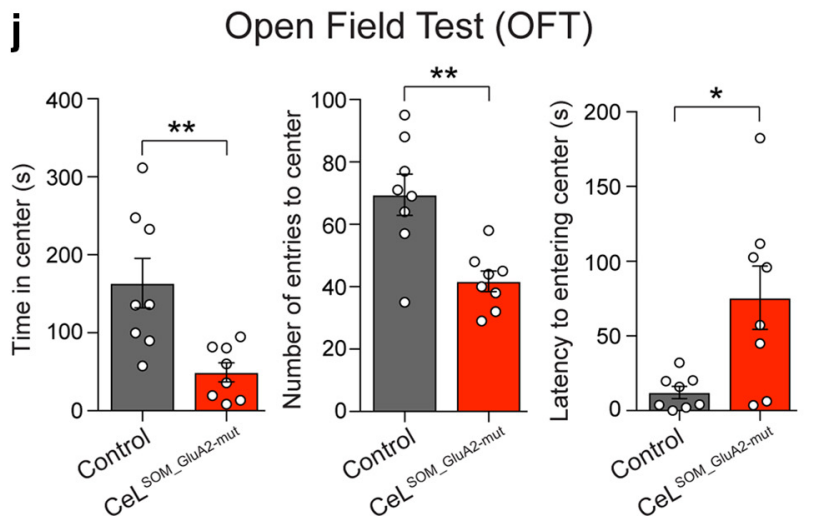

Figure 3. Potentiation of excitatory synaptic drive onto SOM ${ }^{+}$CeL neurons is sufficient to cause enhanced anxiety. $\boldsymbol{a}-\boldsymbol{e}$, Selective deletion of Erbb4 in SOM ${ }^{+} \mathrm{CeL}$ neurons potentiated excitatory synapses onto these neurons and caused increased anxiety in mice. $\boldsymbol{a}$, Left, A schematic of the experimental design. Right, An example image of the SOM ${ }^{+}$CeL neurons expressing Cre-GFP. $\boldsymbol{b}$, Top, A schematic of the recording configuration. Bottom, Representative mEPSC traces recorded from SOM ${ }^{+}$neurons in the CeL of control mice (top) and mice in which Erbb4 was selectively deleted in $\mathrm{SOM}^{+}$CeL neurons (bottom). $\boldsymbol{c}$, Left, Quantification of mEPSC frequency. Right, Quantification of mEPSC amplitude. $\boldsymbol{d}$, Quantification of behavioral parameters in the EPMT. $\boldsymbol{e}$, Quantification of behavioral parameters in the OFT. $\boldsymbol{f}$-j, Selective potentiation of excitatory synaptic transmission onto SOM ${ }^{+}$Cel neurons was sufficient to drive enhanced anxiety in mice. $f$, Left, A schematic of the experimental design. Right, An example image of the $\mathrm{SOM}^{+}$CeL neurons expressing Cre-GFP. $\boldsymbol{g}$, Top, A schematic of the recording configuration. Bottom, Representative mEPSC traces recorded from SOM ${ }^{+}$neurons in the CeL of control mice (top) and mice in which the GluA2 ${ }^{\text {mut }}$ was selectively expressed in SOM ${ }^{+}$CeL neurons (bottom). $\boldsymbol{h}$, Left, Quantification of mEPSC frequency. Right, Quantification of $\mathrm{mEPSC}$ amplitude. $i$, Quantification of behavioral parameters in the EPMT. $j$, Quantification of behavioral parameters in the 0 FT. Data are presented as the mean \pm SEM. ${ }^{*} p<0.05$, ${ }^{* *} p<0.01,{ }^{* * *} p<0.001,{ }^{* * * *} p<0.0001$, n.s. (not significant). 
a
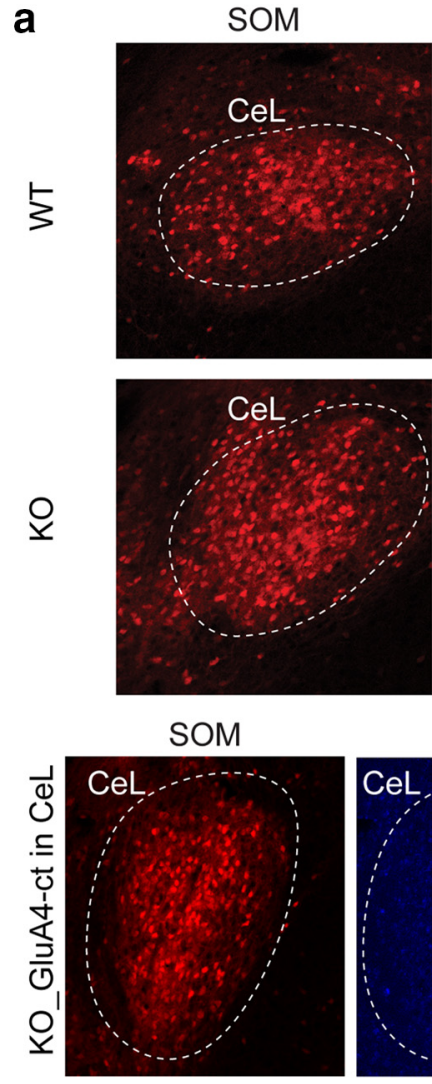

d
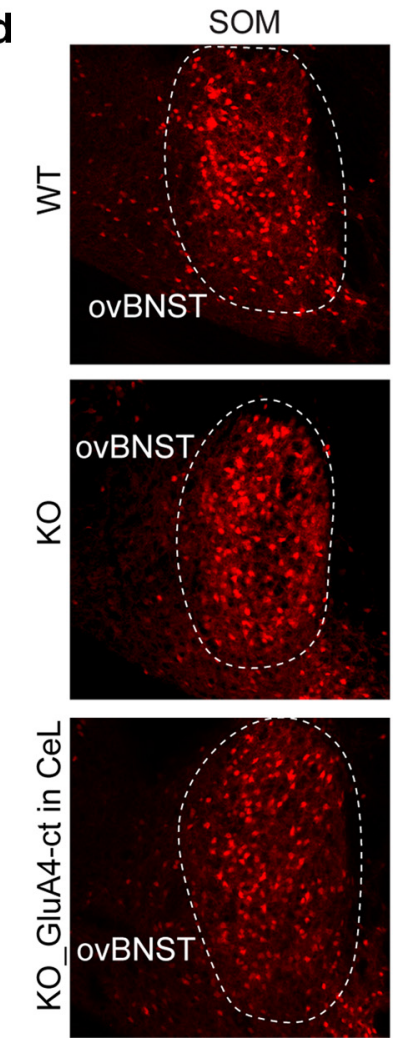

c-Fos
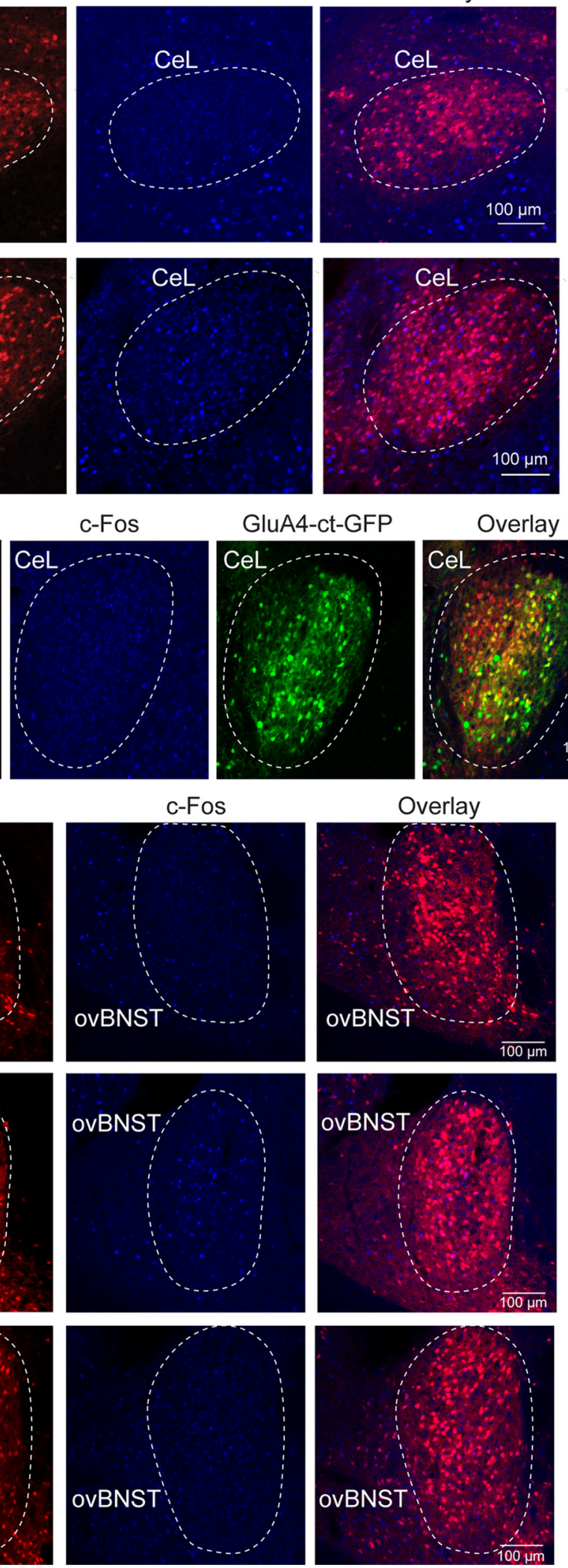
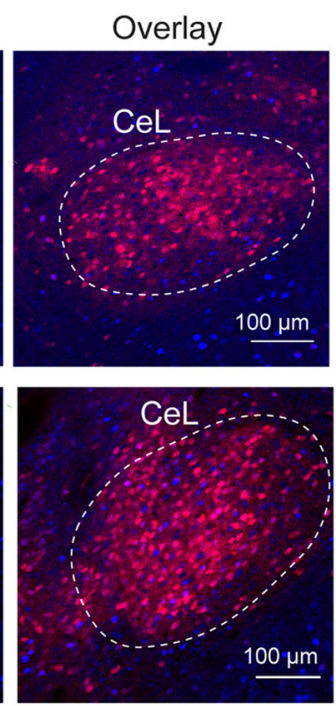

Overlay

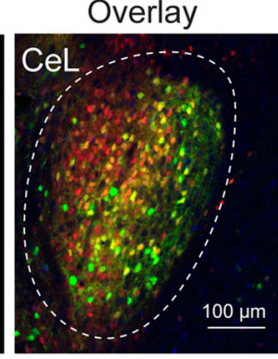

$100 \mu \mathrm{m}$

b
C
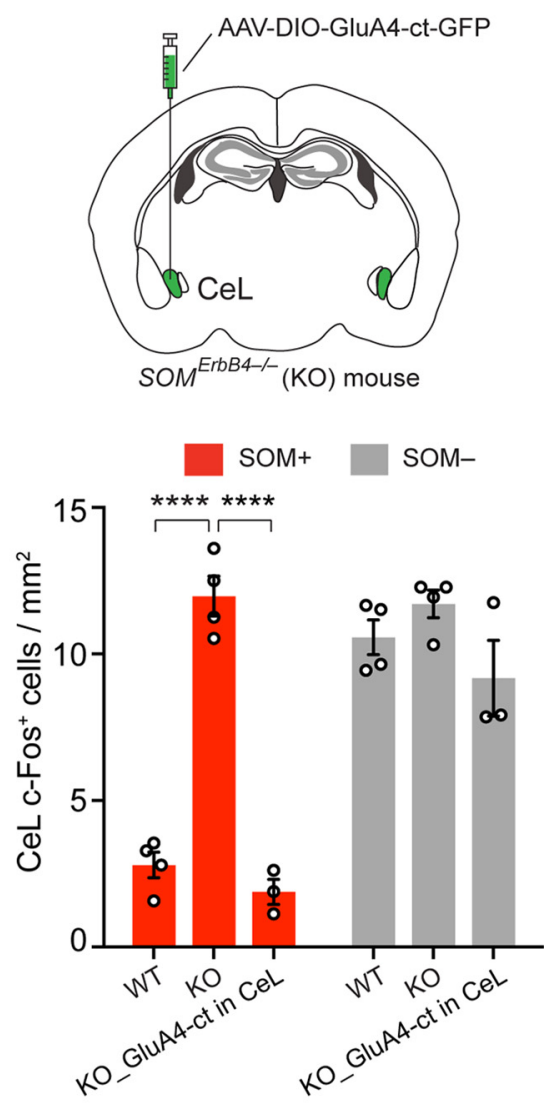

e

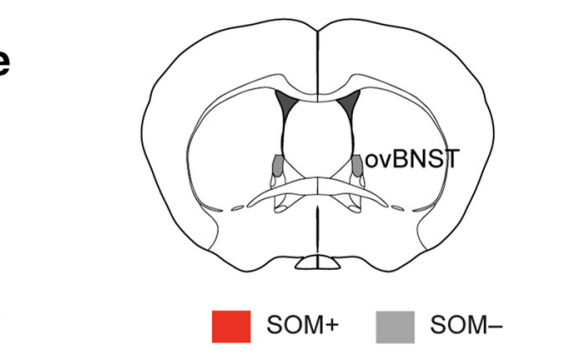

f

b

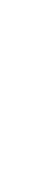

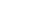

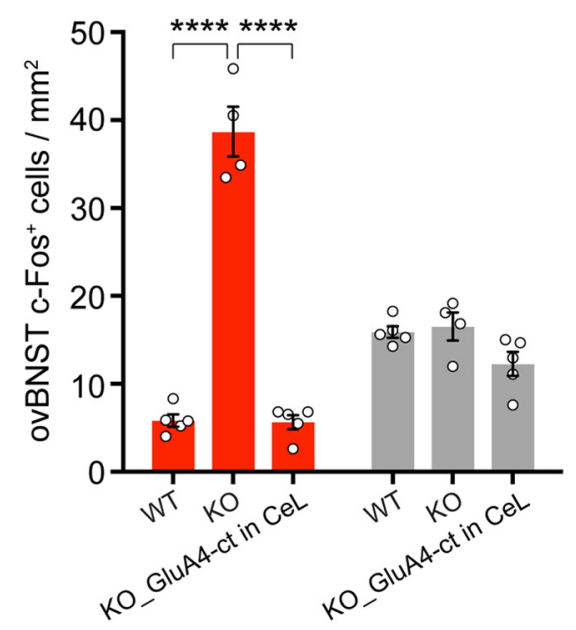

Figure 4. The potentiated excitatory synaptic drive onto SOM ${ }^{+}$CeL neurons causes enhanced activity in these neurons and in SOM ${ }^{+}$dBNST neurons in the ErbB4 mutant mice. $\boldsymbol{a}$, Representative images of the CeL from WT and KO mice (top and middle), and from KO mice in which the rescue molecule GluA4-ct was specifically expressed in SOM ${ }^{+}$CeL neurons (bottom). SOM ${ }^{+}$neurons were labeled with the Ai14 reporter. Basal c-Fos expression was recognized with an antibody. b, A schematic of the experimental design. c, Quantification of c-Fos expression in SOM ${ }^{+}$and SOM ${ }^{-}$CeL $^{-}$ cells, showing that c-Fos levels are increased specifically in SOM ${ }^{+}$CeL cells in the KO mice, and that this increase is normalized by expression of GluA4-ct in SOM ${ }^{+}$CeL neurons. $\boldsymbol{d}$, Same as $\boldsymbol{a}$, except

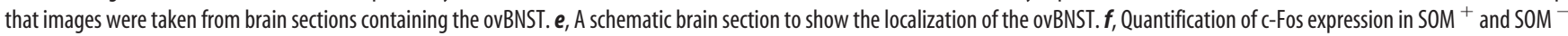
ovBNST cells, showing that c-Fos levels are increased specifically in SOM ${ }^{+}$ovBNST cells in the KO mice, and that this increase is normalized by the expression of GluA4-ct in SOM ${ }^{+}$CeL neurons. Data are presented as the mean \pm SEM in $c$ and $f$. ${ }^{* * *} p<0.0001$. 
(Fig. $2 d$,e: KO_GFP, $n=8$ mice; WT, $n=10$ mice; KO_GluA4ct-GFP, $n=8$ mice; KO_ErbB4-GFP, $n=7$ mice; Fig. $2 d$ : left, time exploring open arms: $F_{(3,29)}=6.66, p=0.0015$; WT vs KO_GFP, $p=0.0025$; KO_GFP vs KO_GluA4-ct-GFP, $p=$ 0.0032 ; KO_GFP vs KO_ErbB4-GFP, $p=0.0028$; middle, number of entries into open arms: $F_{(3,29)}=6.75, p=0.0014$; WT vs KO_GFP, $p=0.0011$; KO_GFP vs KO_GluA4-ct-GFP, $p=$ 0.0028 ; KO_GFP vs KO_ErbB4-GFP, $p=0.0091$; right, latency to first entry into open arms: $F_{(3,29)}=4.11, p=0.015$; WT vs KO_GFP, $p=0.0095$; KO_GFP vs KO_GluA4-ct-GFP, $p=$ 0.052; KO_GFP vs KO_ErbB4-GFP, $p=0.024$; Fig. $2 e$ : left, time exploring center: $F_{(3,29)}=15.9, p<0.0001$; WT vs KO_GFP, $p=$ 0.0001 ; KO_GFP vs KO_GluA4-ct-GFP, $p=0.0007$; KO_GFP vs KO_ErbB4-GFP, $p=0.029$; middle, number of entries into center: $F_{(3,29)}=12.01, p<0.0001$; WT vs KO_GFP, $p<0.0001$; KO_GFP vs KO_GluA4-ct-GFP, $p=0.0531$; KO_GFP vs KO_ErbB4-GFP, $p=0.0051$; right, latency to first entry into center: $F_{(3,29)}=6.54, p=0.0016$; WT vs KO_GFP, $p=0.0006$; KO_GFP vs KO_GluA4-ct-GFP, $p=0.0142$; KO_GFP vs KO_ErbB4-GFP, $p=0.0125$; one-way ANOVA followed by Dunnett's test). These results indicate that the enhanced excitatory synaptic transmission onto $\mathrm{SOM}^{+} \mathrm{CeL}$ neurons is necessary for the expression of elevated anxiety in the HET and KO mice.

Next, we selectively deleted Erbb4 from $\mathrm{SOM}^{+}$neurons in the CeL. To this end, we bred the Som-Flp;Erbb4 flox/flox mice, which

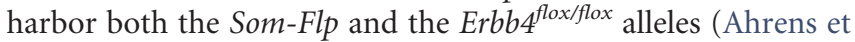
al., 2015), and injected the CeL of these mice with an AAV expressing Cre under the control of Flp (AAV-fDIO-CreGFP; Fig. $3 a)$. In these mice only $\mathrm{SOM}^{+}$neurons in the CeL could express

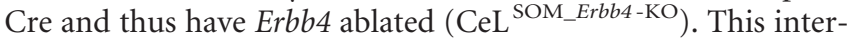
sectional recombinase-based strategy (IRASE) can be generally applied for genetic manipulations with spatial and cell-type specificity (Ahrens et al., 2015; Penzo et al., 2015; Stephenson-Jones et al., 2016). Consistent with the phenotypes observed in the HET and $\mathrm{KO}$ mice (Fig. 1a,b), selective deletion of Erbb4 from SOM ${ }^{+}$ $\mathrm{CeL}$ neurons led to a potentiation of excitatory synaptic transmission onto these neurons (Fig. $3 b, c$ : quantification of mEPSC frequency: control, $n=9$ cells; $\mathrm{CeL}^{\text {SOM_Erbb4-KO}}, n=6$ cells; $\mathrm{df}=$ $13, \mathrm{~T}=3.315, p=0.0076$; quantification of mEPSC amplitude: control, $n=9$ cells; CeL ${ }^{\text {SOM_Erbb4-KO }}, n=6$ cells; $\mathrm{df}=13, \mathrm{~T}=$ $1.737, p=0.1059$; $t$ test), as well as enhanced anxiety in mice [Fig. $3 d$,e: control, $n=8$ mice; CeL ${ }^{\text {SOM_Erbb4-KO }}, n=6$ mice; Fig. $3 d$ : quantification of behavioral parameters in the EPMT: left, time exploring open arms: $\mathrm{df}=12, \mathrm{~T}=4.624, p=0.0006$; middle, number of entries into open arms: $\mathrm{T}=4.68, p=0.0005$; right, latency to first entry into open arms: $\mathrm{T}=2.064, p=0.0613$; Fig. $3 e$ : quantification of behavioral parameters in the OFT: left, time exploring center: $\mathrm{df}=12, \mathrm{~T}=3.754, p=0.0027$; middle, number of entries into center: $\mathrm{T}=3.671, p=0.0032$; right, latency to first entry into center: $\mathrm{T}=3.096 ; p=0.0093 ; t$ test $]$.

Furthermore, to directly enhance the excitatory drive onto $\mathrm{SOM}^{+} \mathrm{CeL}$ neurons independent of ErbB4, we generated a knock-in mouse line that expresses a mutant form of AMPA receptor GluA2 subunit from the ROSA26 locus in a Credependent manner (Rosa26-stop ${ }^{\text {flox }}$-GluA2 ${ }^{\text {mut }}$; see Materials and Methods). This GluA2 ${ }^{\text {mut }}$ has been shown to enhance excitatory synaptic transmission (Hsieh et al., 2006; Weston et al., 2006). We bred the Som-Flp;Rosa26-stop ${ }^{\text {flox }}$-GluA2 $2^{\text {mut }}$ mice and injected the CeL of these mice with the AAV-fDIO-CreGFP to selectively activate the expression of the GluA2 ${ }^{\text {mut }}$ in $\mathrm{SOM}^{+}$CeL neurons (Fig. $3 f$ ). As expected, this IRASE-induced expression of GluA2 ${ }^{\text {mut }}$ in $\mathrm{SOM}^{+} \mathrm{CeL}$ neurons potentiated excitatory synapses onto these neurons [Fig. $3 g, h$ : quantification of mEPSC frequency: control, $n=17$ cells ( 2 mice); CeL ${ }^{\text {SOM_GluA2-mut }}, n=7$ cells (2 mice); $\mathrm{df}=22, \mathrm{~T}=2.963, p=0.0072$; quantification of mEPSC amplitude: control, $n=17$ cells ( 2 mice); CeL ${ }^{\text {SOM_GluA2-mut }}, n=$ 7 cells $(2$ mice $) ; \mathrm{df}=22, \mathrm{~T}=6.995, p<0.0001 ; t$ test $]$ and, moreover, enhanced anxiety in mice (Fig. 3i,j: control, $n=8$ mice; CeL ${ }^{\text {SOM_GluA2-mut }}, n=8$ mice; Fig. $3 i$ : quantification of behavioral parameters in the EPMT: left, time exploring open arms: $\mathrm{df}=14, \mathrm{~T}=3.286, p=0.0054$; middle, number of entries into open arms, $\mathrm{T}=2.639, p=0.0194$; right, latency to first entry into open arms: $\mathrm{T}=3.373, p=0.0046$; Fig. $3 j$ : quantification of behavioral parameters in the OFT: left, time exploring center: $\mathrm{df}=14, \mathrm{~T}=3.38, p=0.0045$; middle, number of entries into center: $\mathrm{T}=3.778, p=0.002$; right, latency to first entry into center: $\mathrm{T}=2.937 ; p=0.0108 ; t$ test). Together, these results indicate that THE deletion of Erbb4 from SOM ${ }^{+} \mathrm{CeL}$ neurons and the resulting increase in excitatory drive onto these neurons are both necessary and sufficient for causing the anxiety phenotypes in the Erbb4 mutant mice.

\section{$\mathrm{SOM}^{+} \mathrm{CeL}$ neurons cause enhanced activity and reduced inhibition in $\mathrm{SOM}^{+}$BNST neurons}

While the role of $\mathrm{SOM}^{+} \mathrm{CeL}$ neurons in learning fear responses has been extensively studied ( $\mathrm{Li}$ et al., 2013; Penzo et al., 2014, 2015; Yu et al., 2016, 2017; Fadok et al., 2017), how these cells regulate anxiety is unknown. Given that the CeL sends strong projections to the BNST (Davis et al., 2010; Oler et al., 2017), a structure that has been heavily implicated in anxiety-related behaviors in both animals and humans, we examined whether the BNST is also affected in the mutant mice. Indeed, we found that both the CeL and the dorsal part of the BNST (dBNST), in which the ovBNST was the major component and which also included areas of the nuclei adjacent to the ovBNST, had increased c-Fos expression in the KO mice compared with the WT mice (Fig. $4 a-f$ ), and that this increase was selective for $\mathrm{SOM}^{+}$neurons in both the CeL and the dBNST (Fig. $4 c, f$ ). These results indicate elevated basal activity of $\mathrm{SOM}^{+}$neurons in the CeL and dBNST of the mutant mice.

To determine whether the elevated activity of $\mathrm{SOM}^{+}$neurons in the $\mathrm{dBNST}$ is dependent on $\mathrm{SOM}^{+}$neurons in the $\mathrm{CeL}$, as were the anxiety phenotypes of these mice (Fig. 2), we suppressed the excitatory synaptic transmission onto $\mathrm{SOM}^{+} \mathrm{CeL}$ neurons using the GluA4-ct (Fig. 4a,b; also see Fig. $2 a-c$ ). Notably, this manipulation reduced c-Fos expression not only in the CeL neurons (Fig. $4 a-c$ ), but also in the $\mathrm{SOM}^{+}$neurons in the dBNST (Fig. $4 d-f$ ) to levels comparable to those in the WT mice (Fig. $4 c$ : WT, $n=4$ mice; KO, $n=4$ mice; KO_GluA4-ct in CeL, $n=3$ mice; SOM ${ }^{+}$cells: $F_{(2,8)}=104.9, p<0.000 ;$ WT vs KO, $p<0.0001 ; \mathrm{KO}$ vs KO_GluA4-ct in CeL, $p<0.0001 ; \mathrm{SOM}^{-}$cells: $F_{(2,8)}=2.6, p=$ 0,134; Fig. 4f: WT, $n=5$ mice; KO, $n=4$ mice; KO_GluA4-ct in CeL, $n=5$ mice; $\mathrm{SOM}^{+}$cells: $F_{(2,11)}=143.4, p<0.000$; WT vs $\mathrm{KO}, p<0.0001 ; \mathrm{KO}$ vs KO_GluA4-ct in CeL, $p<0.0001$; $\mathrm{SOM}^{-}$ cells: $F_{(2,11)}=3.61, p=0.06$; one-way ANOVA followed by Tukey's test). To determine whether there are direct connections from $\mathrm{SOM}^{+} \mathrm{CeL}$ neurons to the dBNST, we did retrograde tracing and ChR2 (the light-gated cation channel; Zhang et al., 2006)assisted circuit mapping. We found that $\mathrm{SOM}^{+} \mathrm{CeL}$ neurons indeed innervate the dBNST (Fig. $5 a$ ), where they form functional synapses with both the $\mathrm{SOM}^{+}$neurons and the $\mathrm{SOM}^{-}$ neurons [Fig. 5b-e; Fig. 5e: $\mathrm{SOM}^{+}, n=8$ cells (2 mice); $\mathrm{SOM}^{-}, n=7$ cells ( 2 mice); $\mathrm{df}=13, \mathrm{~T}=09757, p=0.3470, t$ test]. These results suggest that enhanced excitatory drive onto 
a

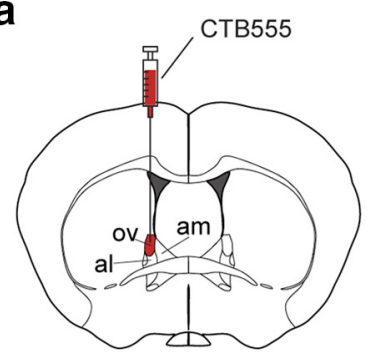

SOM-Cre;H2B-GFP mouse

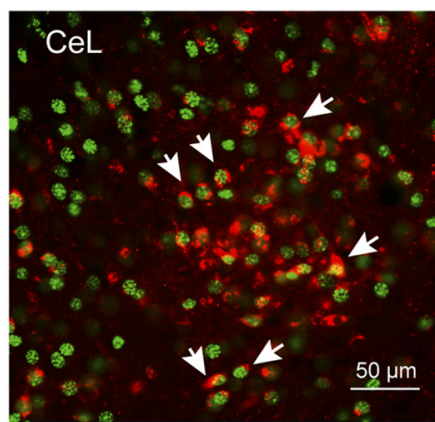

d

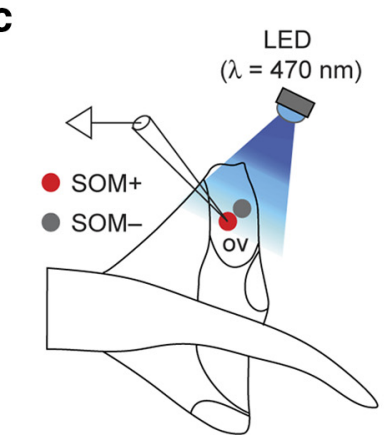

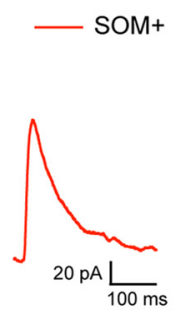

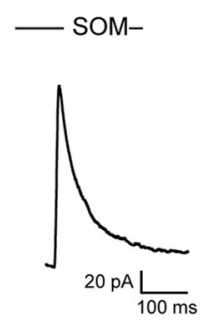

b

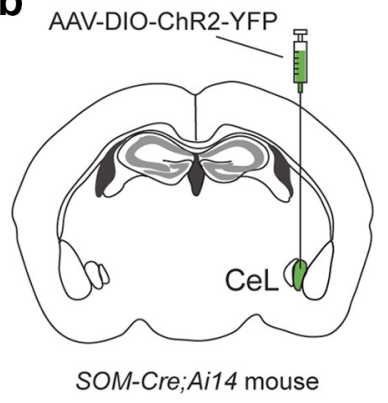

e

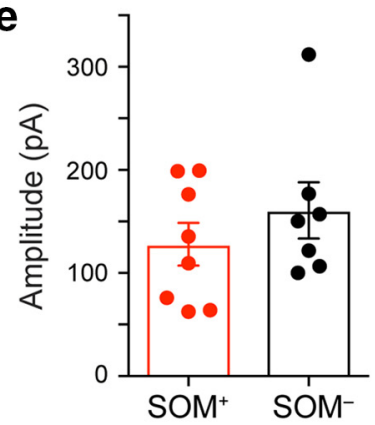

Figure 5. SOM ${ }^{+}$CeL neurons innervate neurons in the ovBNST. $\boldsymbol{a}$, Left, A schematic of the experimental approach. Right, CTB-labeled neurons can be detected in the CeL (red), many of which are SOM ${ }^{+}$(green; arrows). CTB, Cholera Toxin subunit B. $\boldsymbol{b}$, A schematic of the experimental approach. $\boldsymbol{c}$, A schematic of the recording configuration. $\boldsymbol{d}$, Example traces of the IPSCs recorded from $\mathrm{a} \mathrm{SOM}^{+}$(red) and a SOM ${ }^{-}$(black) ovBNST neuron in response to optogenetic stimulation of the inputs from SOM ${ }^{+}$CeL neurons. $\boldsymbol{e}$, Quantification of IPSC amplitude. Data are presented as the mean \pm SEM in $\boldsymbol{e}$.

$\mathrm{SOM}^{+} \mathrm{CeL}$ neurons causes the increased activity in both $\mathrm{SOM}^{+}$ CeL neurons and $\mathrm{SOM}^{+}$dBNST neurons in the mutant mice.

To identify the possible cellular processes underlying the enhanced basal activity in $\mathrm{SOM}^{+} \mathrm{dBNST}$ cells in the mutant mice, we recorded synaptic transmission onto dBNST neurons (Fig. $6 a)$. We found that the inhibitory synaptic transmission onto $\mathrm{SOM}^{+}$dBNST neurons, measured as the frequency and amplitude of sIPSCs, was markedly reduced in the mutant mice compared with the WT mice [Fig. $6 b, c$; Fig. $6 c$ : left, quantification of sIPSC frequency: $\mathrm{SOM}^{+}: \mathrm{WT}, n=21$ cells ( 4 mice); KO/HET, $n=24$ cells $(4$ mice $) ; \mathrm{df}=43, \mathrm{~T}=8.3, p<0.0001 ; \mathrm{SOM}^{-}: \mathrm{WT}$, $n=5$ cells $(3$ mice $) ; \mathrm{KO} / \mathrm{HET}, n=8$ cells $(4$ mice $) ; \mathrm{df}=11, \mathrm{~T}=$ $0.58, p=0.57)$; right, quantification of sIPSC amplitude: $\mathrm{SOM}^{+}$: $\mathrm{df}=43, \mathrm{~T}=4.47, p<0.0001 ; \mathrm{SOM}^{-}: \mathrm{df}=11, \mathrm{~T}=0.92, p=$ 0.38 ; unpaired $t$ test]. Furthermore, this synaptic change can be "rescued" by suppression of the excitatory synaptic transmission onto $\mathrm{SOM}^{+} \mathrm{CeL}$ neurons in the mutant mice [Fig. 6d-f; Fig. $6 f$ : left, quantification of sIPSC frequency: KO_GFP, $n=19$ cells ( 3 mice); KO_GluA4-ct-GFP, $n=19$ cells ( 3 mice); $\mathrm{df}=36, \mathrm{~T}=$ $7.36, p<0.0001$ ); right, quantification of sIPSC amplitude: $\mathrm{df}=$ $36, \mathrm{~T}=4.85, p<0.0001$; unpaired $t$ test], using the same rescue strategy as described above (Fig. $2 a-c$ ). These results suggest that the increased excitatory drive onto $\mathrm{SOM}^{+} \mathrm{CeL}$ neurons causes a reduction in tonic inhibition onto $\mathrm{SOM}^{+}$dBNST neurons, thereby leading to the increased activity in the latter population in the mutant mice.

\section{$\mathrm{SOM}^{+} \mathrm{dBNST}$ neuron activity is essential for the expression} of anxiety

To first determine whether the reduced inhibitory tone or increased activity of $\mathrm{SOM}^{+}$dBNST neurons is critical for the expression of enhanced anxiety in the mutant mice, we suppressed the output of these neurons by infecting them with an AAV ex- pressing the tetanus toxin light chain (TeLC; Fig. 7a), which blocks neurotransmitter release (Murray et al., 2011; Yu et al., 2016; Yu et al., 2017). This manipulation markedly reduced the anxiety phenotypes of the mutant mice (Fig. 7b,c; Fig. 7b: left, quantification of time spent on the open are in the EPMT: KO_GFP, $n=8$; KO_TeLC-GFP, $n=8$; $\mathrm{df}=14$, T $=3.78$, $p=$ 0.002 ; right, quantification of time spent in the center in the OFT: $\mathrm{df}=14, \mathrm{~T}=3.117, p=0.0076$; unpaired $t$ test; Fig. $7 c$ : gray line, $R^{2}=0.515, p=0.0450$ by a linear regression).

To determine whether reduced inhibition onto $\mathrm{SOM}^{+}$ dBNST neurons is sufficient to drive anxiety, we selectively weakened the GABAergic synapses onto these neurons. To achieve this goal, we injected the dBNST of Som-Flp;Gabrg $2^{\text {flox }}$ mice (Wulff et al., 2007; Stephenson-Jones et al., 2016) with the AAV-fDIOCreGFP (Ahrens et al., 2015; Penzo et al., 2015; Stephenson-Jones et al., 2016; Fig. 7d; also see Fig. 3, which used the same IRASE approach). In these mice, only the $\mathrm{SOM}^{+}$neurons within the dBNST could express Cre and thus have the $\gamma 2$ subunit of $\mathrm{GABA}_{\mathrm{A}}$ receptor ablated ( $\mathrm{dBNST}^{\mathrm{SOM}-\gamma 2-\mathrm{KO}}$ ). We previously used this approach to reduce $\mathrm{GABA}_{\mathrm{A}}$-mediated synaptic transmission (Stephenson-Jones et al., 2016). Compared with control mice, the dBNST ${ }^{\text {SOM_r2-KO }}$ mice showed enhanced anxiety in both the EPMT and OFT [Fig. 7e,f; Fig. 7e: quantification of measures of anxiety in the EPMT (left) and OFT (right) in the $\gamma 2-\mathrm{KO}$ and $\boldsymbol{\gamma} 2$-WT mice ( $\boldsymbol{\gamma} 2$-WT, $n=9$ mice; $\boldsymbol{\gamma} 2-\mathrm{KO}, n=10$ mice; EPMT: $\mathrm{T}=2.727, \mathrm{df}=17, p=0.0143$; OFT: $\mathrm{T}=2.889, \mathrm{df}=17, p=$ 0.0102; unpaired $t$ test); Fig. $7 f$ : gray line, $R^{2}=0.71, p=0.0023$ by a linear regression]. These results indicate that reduced inhibition onto or increased activity of $\mathrm{SOM}^{+} \mathrm{dBNST}$ neurons is required for the expression of the anxiety phenotypes in the ErbB4 mutant mice (Fig. $7 a-c$ ) and is also sufficient to drive anxiety in ErbB4 wild-type mice (Fig. $7 d-f$ ). 
a

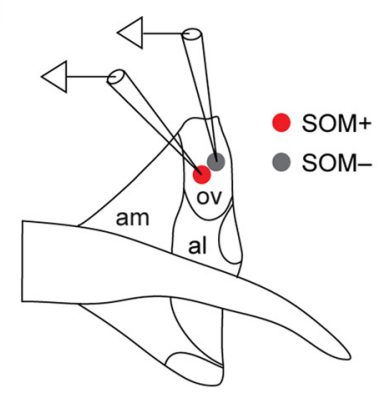$$
S^{\text {EOrbB4+- }} ; \text { Ai14 (HET), }
$$

or SOM ${ }^{\text {ErbB4- }} ;$ Ai14 (KO) mouse

$$
\text { SOM }{ }^{\mathrm{ErbB} 4++/} ; A i 14 \text { (WT), }
$$

b

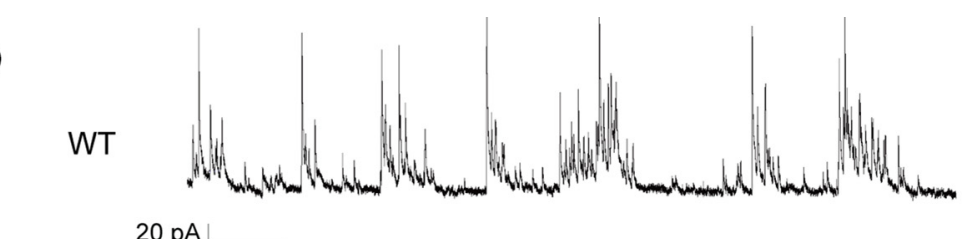

$20 \mathrm{pA} \perp 2$

KO

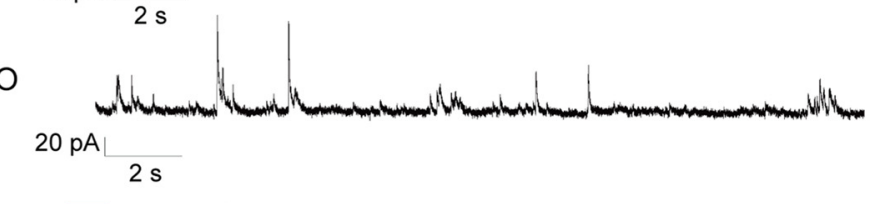

C
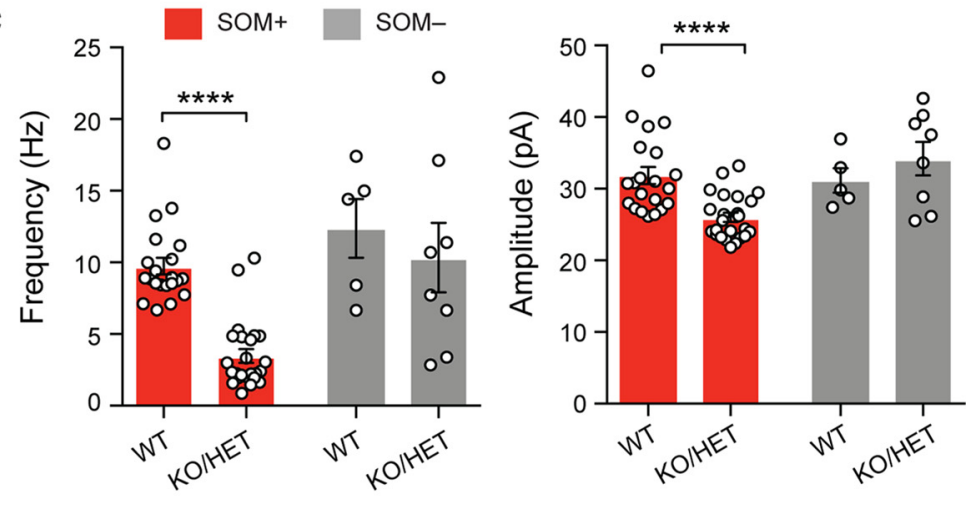

d

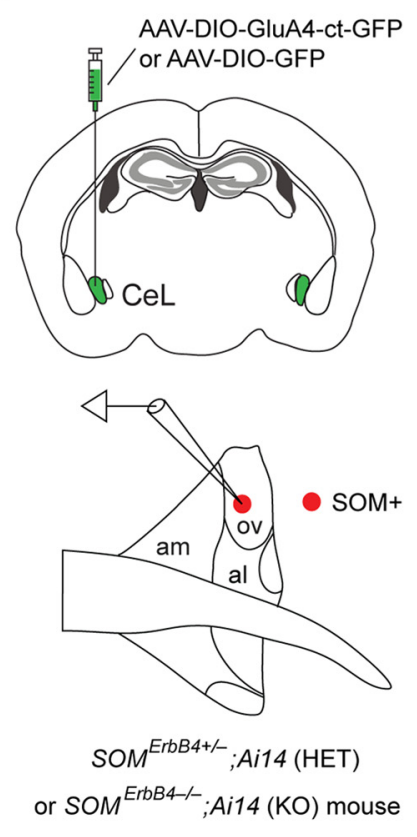

e<smiles>[O+][Os]</smiles>
$20 \mathrm{pA}$
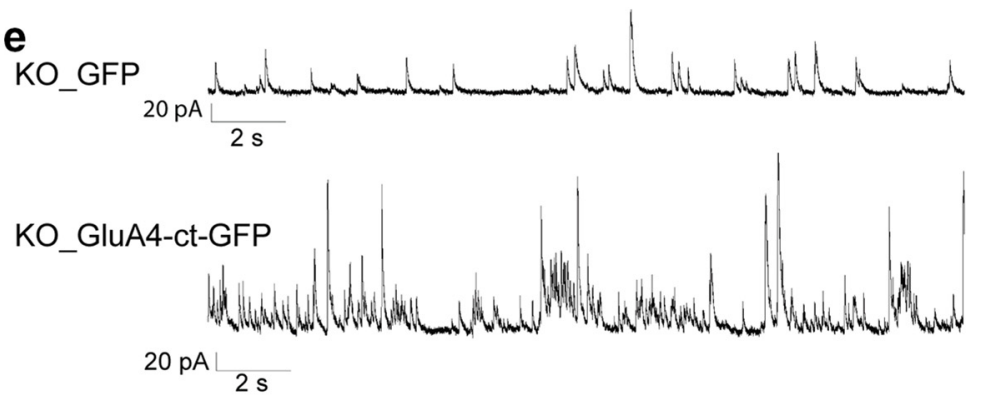

\section{f}

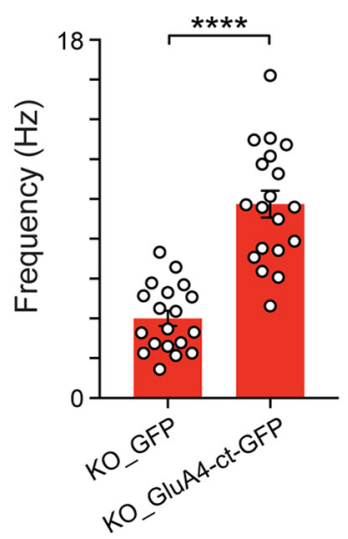

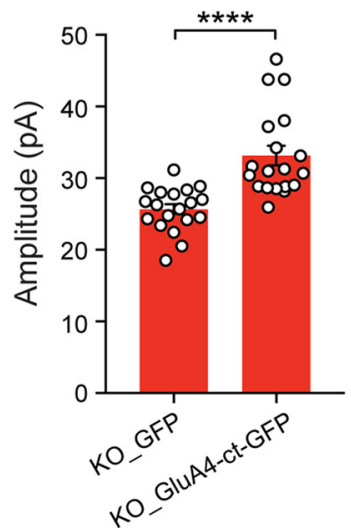

Figure 6. The potentiated excitatory synaptic drive onto $\mathrm{SOM}^{+}$CeL neurons causes disinhibition of SOM ${ }^{+}$ovBNST neurons in the ErbB4 mutant mice. $a$, A schematic of the recording configuration. $\boldsymbol{b}$, Representative sIPSC traces recorded from SOM ${ }^{+}$neurons in the ovBNST of WT mice (top) and ErbB4 mutant mice (bottom). $\boldsymbol{c}$, Left, Quantification of sIPSC frequency. Right, Quantification of SIPSC amplitude. $\boldsymbol{d}$, A schematic of the experimental design.e, Representative sIPSC traces recorded from SOM ${ }^{+}$neurons in the ovBNST of a KO mouse (top) and a KO mouse in which GluA4-ct was selectively expressed in SOM ${ }^{+}$CeL neurons (bottom). $f$, Left, Quantification of sIPSC frequency. Right, Quantification of sIPSC amplitude. Data are presented as the mean \pm SEM in cand $f^{* * * *} p<0.0001$.

\section{Dynorphin signaling modulates inhibition in the dBNST} and anxiety

How, then, an enhancement in the activity of $\mathrm{SOM}^{+} \mathrm{CeL}$ neurons, which provide GABAergic outputs to the BNST (Fig. 5), is coupled with reduced inhibition onto $\mathrm{SOM}^{+} \mathrm{dBNST}$ neurons in the mutant mice? In addition to GABA, CeL neurons also express various kinds of neuropeptides that can act as neurotransmitters (Cassell and Gray, 1989; Gray and Magnuson, 1992; Marchant et al., 2007; Poulin et al., 2009; McCall et al., 2015; Sanford et al., 2017) and modulate circuit function and behavior (Davis et al., 2010; Sanford et al., 2017). One possibility is that enhanced activity of $\mathrm{SOM}^{+} \mathrm{CeL}$ neurons leads to homeostatic changes in 
a
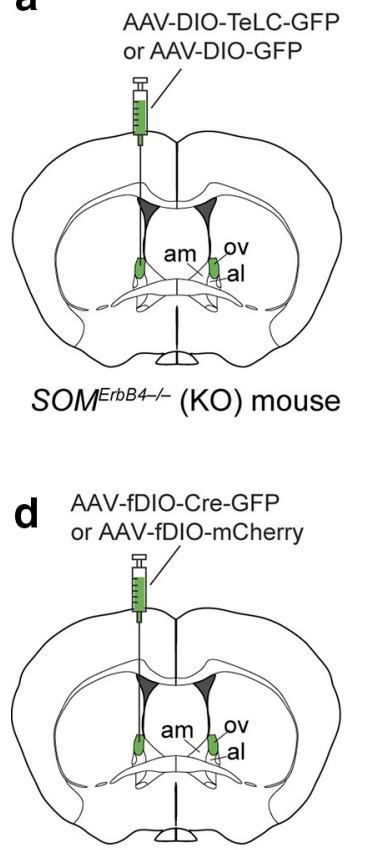

Som-Flp;Gabrg2 flox mouse b
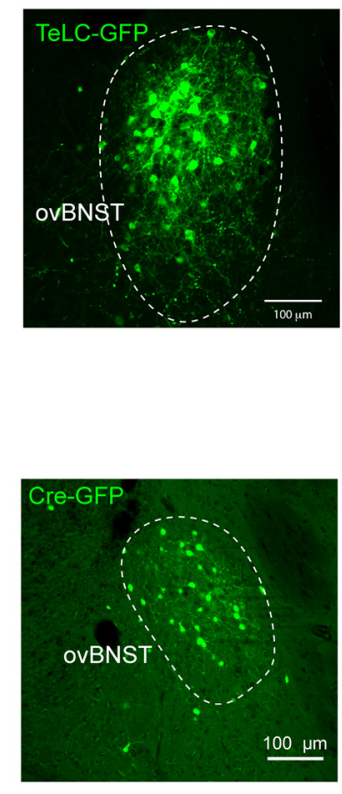

e

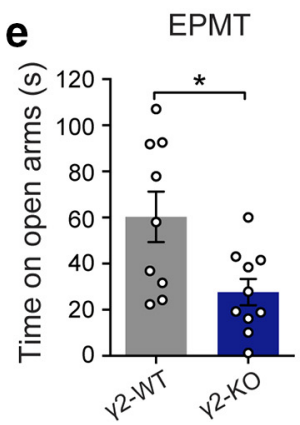

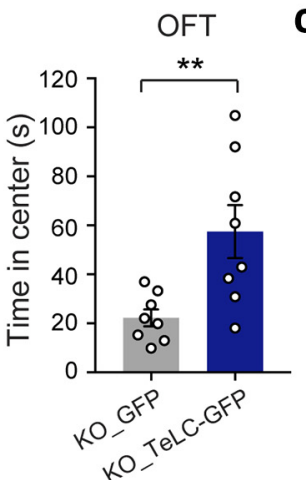
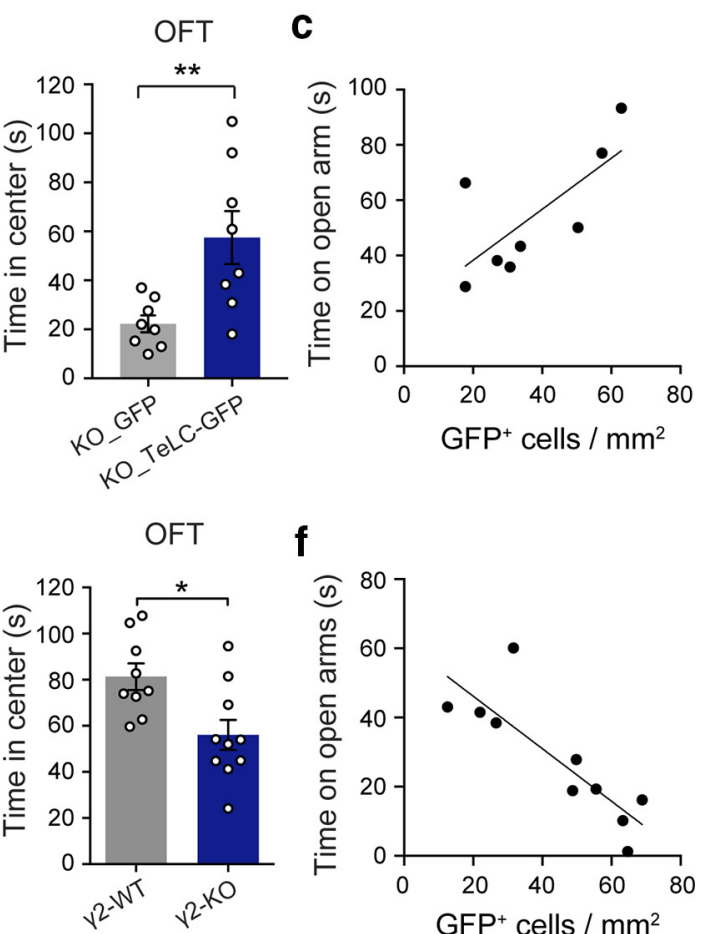

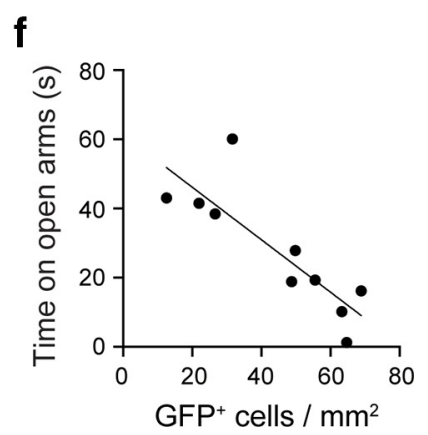

Figure 7. The activity of $\mathrm{SOM}^{+}$dBNST neurons is required for the enhanced anxiety in the ErbB4 mutant mice and is sufficient to drive anxiety in ErbB4 wild-type mice. $\boldsymbol{a}-\boldsymbol{f}$, For all these manipulations, we aimed at targeting the ov. However, due to the fact that the ovBNST is small and very close to the adjacent nuclei, our manipulations may have also affected other BNST nuclei,

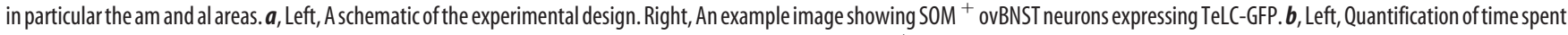
on the open are in the EPMT. Right, Quantification of time spent in the center in the OFT. c, The density of SOM ${ }^{+}$ovBNST neurons infected with the TeLC-GFP virus correlated with the decrease in anxiety measured by the time spend on open arms during the EPMT. $\boldsymbol{d}$, Left, Schematics of the experimental design. Right, An example image of the ovBNST in a Som-FIp; Gabrg $2^{f l o x}$ mouse, showing the expression of Cre-GFP in SOM ${ }^{+}$ovBNST neurons. $e$, Quantification of measures of anxiety in the EPMT (left) and 0FT (right) in the $\gamma 2$-K0 and $\gamma 2$-WT mice. Ablation of $\gamma 2$ increases anxiety. $f$, The density of SOM ${ }^{+}$ovBNST neurons infected with the AAV-fDIO-Cre-GFP virus correlated with the increase in anxiety measured by the time spend on open arms during the EPMT. Data are presented as the mean \pm SEM in $\boldsymbol{b}$ and $\boldsymbol{e}$. ${ }^{*} p<0.05,{ }^{* *} p<0.01$.

these neurons in neuropeptide-mediated signaling, which affects the GABAergic inputs onto $\mathrm{SOM}^{+} \mathrm{dBNST}$ neurons. To identify which neuropeptides are selectively expressed by $\mathrm{SOM}^{+} \mathrm{CeL}$ neurons, we assessed the gene expression profile in these neurons using the RiboTag and RNA-seq strategy (Sanz et al., 2009) in the Som-cre;RiboTag mice (see Materials and Methods). We found that $P d y n$, the gene encoding the precursor of dynorphin, was the most highly enriched neuropeptide in $\mathrm{SOM}^{+} \mathrm{CeL}$ cells after Somatostatin (Sst) itself, followed by Tac2 and Nts, while Penk and $C c k$ were significantly depleted in these neurons compared with the entire CeL population (Fig. $8 a, b$ ).

Dynorphin is a good candidate for mediating some of the physiological and behavioral phenotypes of the mutant mice because it suppresses inhibitory synaptic transmission from the CeA to the dBNST ( $\mathrm{Li}$ et al., 2012), its expression is regulated by stress (Donahue et al., 2015), and it is implicated in anxiety (Knoll et al., 2007; Wittmann et al., 2009; Crowley et al., 2016), aversion, and depression (Bruchas and Chavkin, 2010; Bruchas et al., 2010; Knoll and Carlezon, 2010; Crowley and Kash, 2015). Notably, we found that Pdyn mRNA levels in the CeL were increased in the KO mice compared with the WT mice (Fig. $8 c, d$; $\mathrm{WT}, n=3$ mice; KO/HET, $n=3$ mice; $\mathrm{T}=6.198$, $\mathrm{df}=4, p=$ 0.0034 , unpaired $t$ test). To determine whether enhanced dynorphin signaling could be the cause of the reduced inhibition onto $\mathrm{SOM}^{+} \mathrm{dBNST}$ neurons in the mutant mice, we inhibited dynorphin signaling by treating acute BNST slices with norBNI, a selective antagonist of the dynorphin receptor $\kappa$ opioid receptor $(\mathrm{Li}$ et al., 2012; Crowley et al., 2016). This manipulation markedly enhanced the inhibitory synaptic transmission onto $\mathrm{SOM}^{+}$ dBNST neurons in the mutant mice, but not the WT mice [Fig. $8 e-g$; Fig. $8 g$ : KO/HET: control, $n=24$ cells ( 4 mice); norBNI, $n=10$ cells ( 3 mice); WT: control, $n=21$ cells ( 4 mice); norBNI, $n=8$ cells ( 2 mice); left, quantification of sIPSC frequency: $F_{(3,59)}=32.44, p<0.0001 ; \mathrm{KO} / \mathrm{HET}$ control vs $\mathrm{KO} / \mathrm{HET}$ norBNI, $p<0.0001$; KO/HET control vs WT control, $p<0.0001$; right, quantification of sIPSC amplitude: $F_{(3,59)}=10.98, p<$ $0.0001 ; \mathrm{KO} / \mathrm{HET}$ control vs KO/HET norBNI, $p=0.0002 ; \mathrm{KO} /$ HET control vs WT control, $p<0.0001$; one-way ANOVA followed by Tukey's test]. To test whether enhanced dynorphin signaling in vivo accounts for the behavioral phenotypes of the mutant mice, we infused norBNI into the dBNST in behaving mice (Fig. 8h). Remarkably, this treatment reduced the anxiety phenotypes in the mutant mice in the EPMT and OFT to levels similar to those of the WT mice (Fig. $8 \mathrm{i}$ : KO/HET: saline, $n=12$ mice; norBNI, $n=6$ mice; WT: saline, $n=5$ mice; norBNI, $n=$ 5 mice; left, quantification of time spent on the open arms in the EPMT: $F_{(3,24)}=4.912, p=0.0084 ; \mathrm{KO} / \mathrm{HET}$ saline vs $\mathrm{KO} / \mathrm{HET}$ norBNI, $p=0.042$; WT saline vs KO/HET saline, $p=0.0335$; right, quantification of time spent in the center in the OFT: $F_{(3,24)}=2.956, p=0.05 ; \mathrm{KO} / \mathrm{HET}$ saline vs $\mathrm{KO} / \mathrm{HET}$ norBNI, $p=0.0461$; one-way ANOVA followed by Tukey's test). These results suggest that dynorphin signaling onto the dBNST in the mutant mice is tonically increased, causing, at least in part, the reduction in inhibitory synaptic drive onto $\mathrm{SOM}^{+}$dBNST neurons and, hence, the enhanced anxiety. 

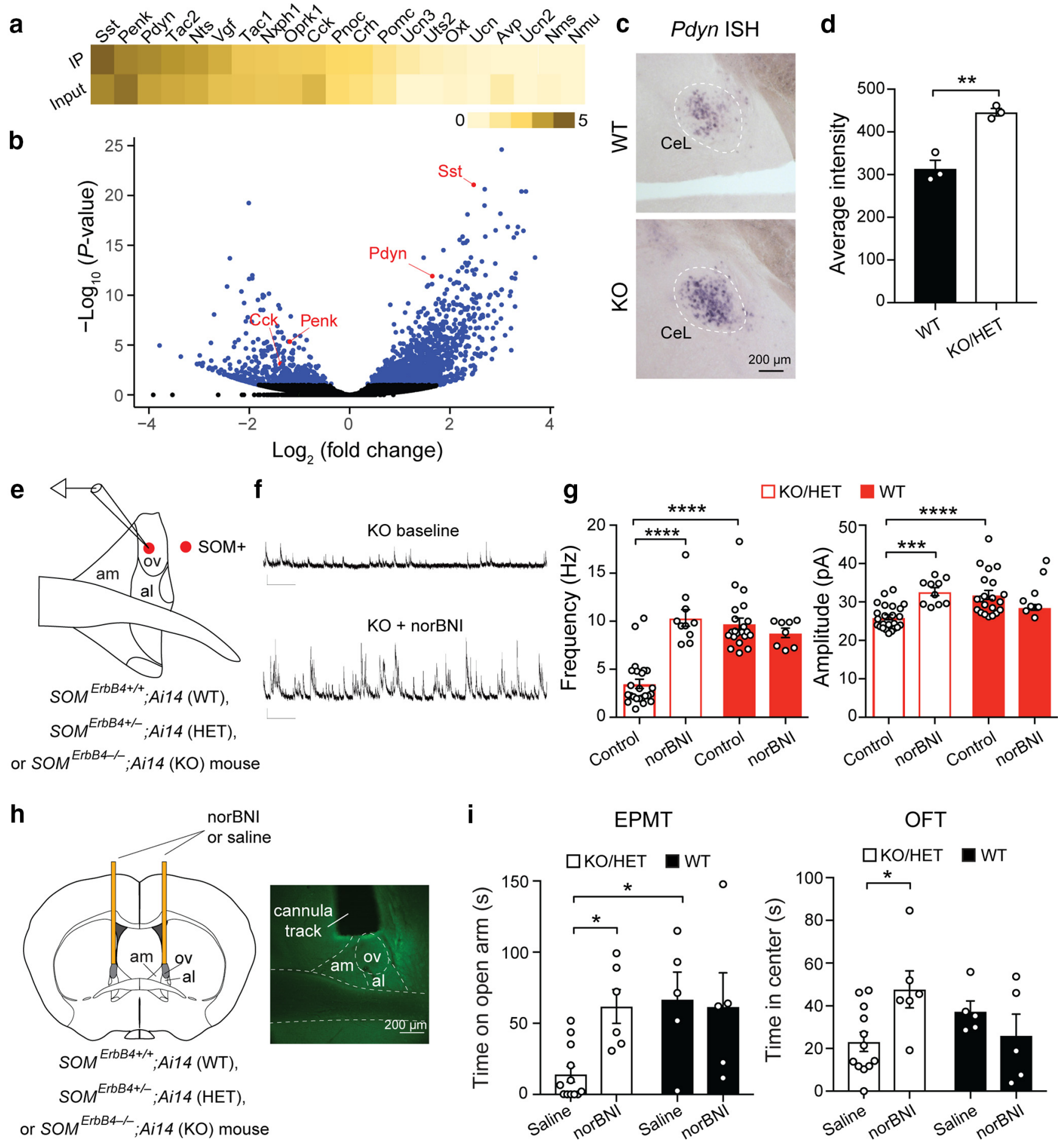

Figure 8. Enhanced dynorphin signaling in the ErbB4 mutant mice causes ovBNST disinhibition and enhanced anxiety. $\boldsymbol{a}$, Heatmap depicting neuropeptide gene expression levels [log ${ }_{10}$ (normalized read counts + 1)] in CeL IP and input samples, which represent SOM ${ }^{+}$cells and all cells, respectively; genes are ranked by abundance in SOM ${ }^{+}$cells. $\boldsymbol{b}$, Volcano plot showing log ${ }_{2}$ (fold change; IP against input) plotted against $-\log _{10}$ (Bonferroni-Hochberg-adjusted $p$ value). Significantly differentially expressed genes are colored blue. Select neuropeptides are highlighted in red. c, Bright-field microscopy images of the in situ hybridization of Pdyn in the CeL of WT mice (top) and KO mice (bottom). $\boldsymbol{d}$, Quantification of Pdyn expression by measuring the average pixel intensity. $\boldsymbol{e}$, A schematic of the recording configuration. $\boldsymbol{f}$, Representative sIPSC traces recorded from a SOM ${ }^{+}$ovBNST neuron in a K0 mouse before (top) and after (bottom) application of $100 \mathrm{~nm}$ norBNI. $\boldsymbol{g}$, Left, Quantification of sIPSC frequency. Right, Quantification of sIPSC amplitude. $\boldsymbol{h}$, Left, A schematic of the experimental configuration. Microinfusion cannulae were implanted bilaterally above the ovBNST. Right, A representative image of the BNST, showing the track of an implanted cannula above the ovBNST. $\boldsymbol{i}$, Microinfusion of norBNI reduces anxiety in KO/HET mice but does not affect anxiety in WT mice. Left, Quantification of time spent on the open arms in the EPMT. Right, Quantification of time spent in the center in the 0 FT. Data are presented as the mean \pm SEM in $\boldsymbol{d}, \boldsymbol{g}$, and $\boldsymbol{i}$. ${ }^{*} p<0.05,{ }^{* *} p<0.01,{ }^{* * *} p<0.001,{ }^{* * *} p<0.0001$.

Stress recapitulates in wild-type mice the anxiety and cellular phenotypes of the mutant mice

Finally, we tested whether similar changes in the CeL and the dBNST could be involved in the increase in anxiety induced by stress in ErbB4 wild-type mice. To this end, we subjected SomCre;Ai14 mice, in which $\mathrm{SOM}^{+}$cells are red fluorescent, to uncontrollable and unpredictable footshocks (Wang et al., 2014; Perova et al., 2015). This procedure increased the anxiety levels in 

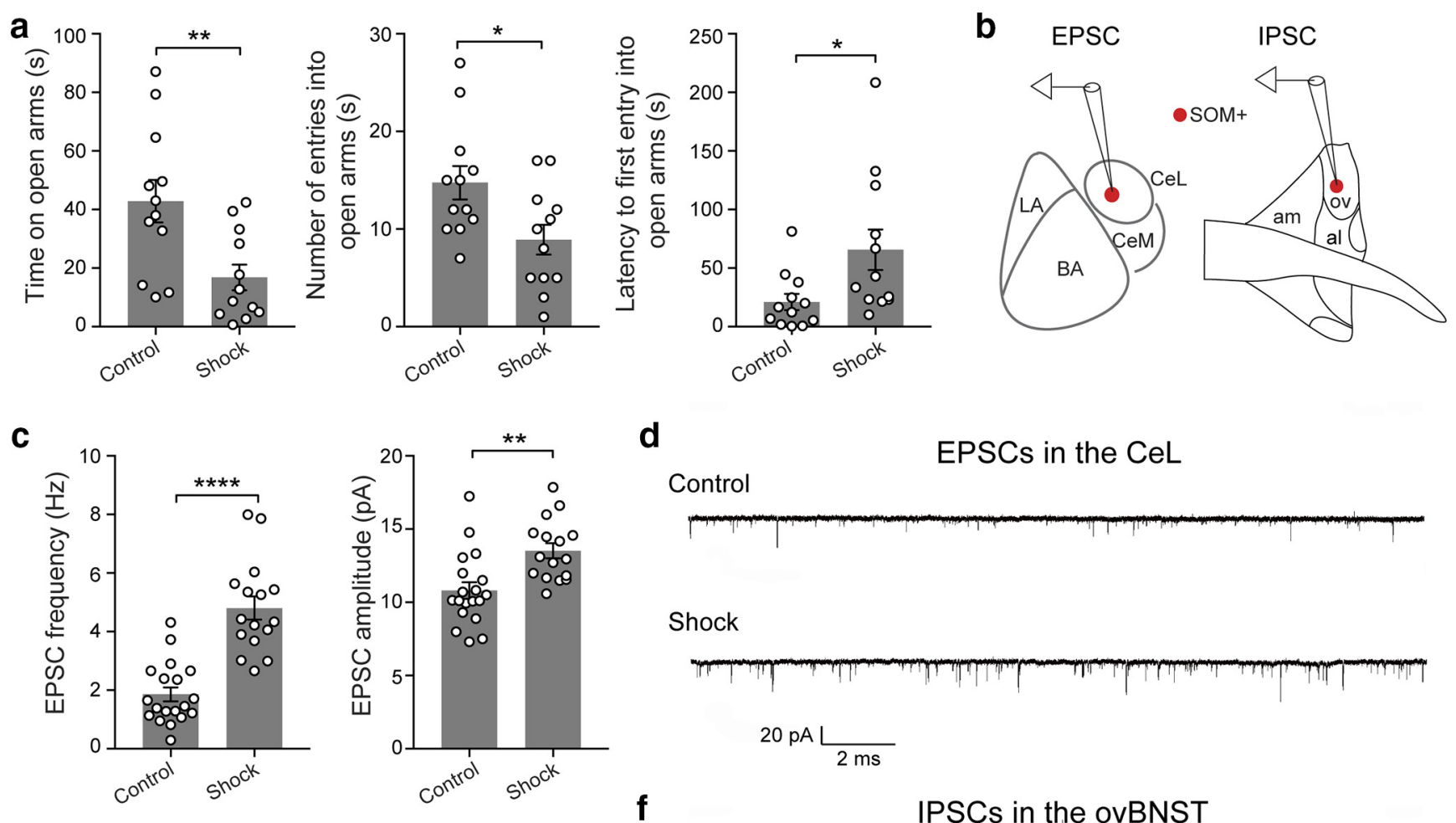

d

Control

EPSCs in the CeL

Shock

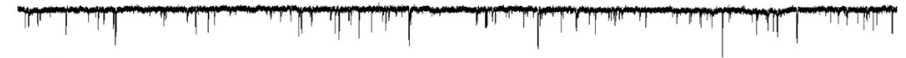

$20 \mathrm{pAL}$

f

e
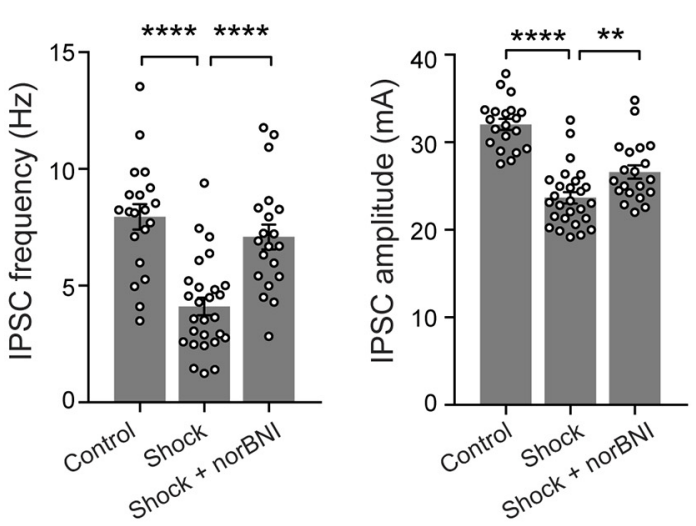

IPSCs in the ovBNST

Control

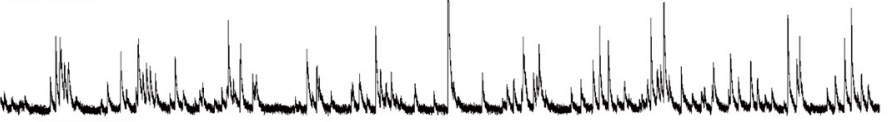

Shock

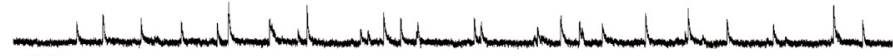

Shock + norBNI

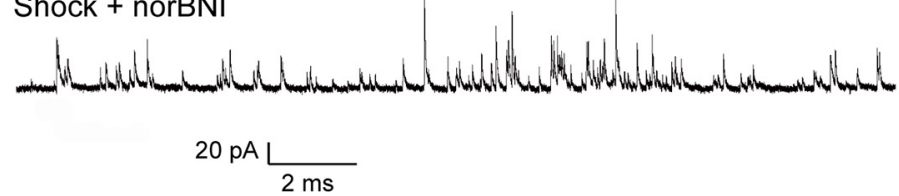

Figure 9. Stress induces behavioral and cellular changes in the CeL and ovBNST that mimic those in the ErbB4 mutant mice. $\boldsymbol{a}$, Stress induced by uncontrollable and unpredictable footshocks increased anxiety in the EPMT. $\boldsymbol{b}$, Schematics of the recording configurations. c, Quantification of the frequency (left) and amplitude (right) of mEPSCs recorded from SOM ${ }^{+}$CeL neurons. $\boldsymbol{d}$, Representative mEPSC traces recorded from a neuron in a control mouse (top) and a neuron in a stressed mouse (bottom). $\boldsymbol{e}$, Quantification of the frequency (left) and amplitude (right) of sIPSCs recorded from SOM ${ }^{+}$ovBNST neurons. $f$, Example traces of sIPSC recorded from neurons of the three experimental groups. Data are presented as the mean \pm SEM in $a, c$, and $\boldsymbol{e} .{ }^{*} p<0.05$, ${ }^{* *} p<$ $0.01,{ }^{* * * *} p<0.0001$.

these mice (Fig. $9 a$ : control, $n=12$ mice; shock, $n=12$ mice; left, time on open arms: $\mathrm{T}=3.086, \mathrm{df}=22, p=0.0054$; middle, number of entries into open arms: $\mathrm{T}=2.553 \mathrm{df}=22, p=$ 0.0181 ; right, latency to first entry into open arm: $\mathrm{T}=2.386, \mathrm{df}=$ $22, p=0.0261$; unpaired $t$ test). We subsequently prepared acute slices from these mice, in which we recorded mEPSCs and mIPSCs from SOM ${ }^{+}$CeL neurons and $\mathrm{SOM}^{+}$dBNST neurons, respectively (Fig. 9b). We found that the excitatory synaptic transmission onto $\mathrm{SOM}^{+} \mathrm{CeL}$ neurons was higher, while the inhibitory synaptic transmission onto $\mathrm{SOM}^{+} \mathrm{dBNST}$ neurons was lower in the stressed mice than in the control mice (Fig. $9 c-f$ ). Furthermore, the reduced inhibitory synaptic transmission onto $\mathrm{SOM}^{+} \mathrm{dBNST}$ in the stressed mice can be normalized by norBNI [Fig. 9e,f; Fig. 9c: quantification of the frequency (left) and amplitude (right) of mEPSCs recorded from $\mathrm{SOM}^{+} \mathrm{CeL}$ neurons; control, $n=19$ cells ( 2 mice); shock, $n=16$ cells ( 2 mice); frequency, $\mathrm{T}=6.65, \mathrm{df}=33, p<0.0001$; amplitude, $\mathrm{T}=3.474$, $\mathrm{df}=33, p=0.0015$; unpaired $t$ test; Figure $9 e$ : quantification of the frequency (left) and amplitude (right) of sIPSCs recorded from $\mathrm{SOM}^{+}$ovBNST neurons; control, $n=20$ cells ( 3 mice); shock, $n=27$ cells ( 5 mice); shock + norBNI, $n=20$ cells ( 5 mice); frequency: $F_{(2,64)}=19.7, p<0.0001$; control vs shock, $p<0.0001$; shock vs shock + norBNI, $p<0.0001$; amplitude: $F_{(2,64)}=38.91, p<0.0001$; control vs shock, $p<0.0001$; shock vs shock + norBNI, $p=0.0083$; one-way ANOVA followed by Tukey's test], indicating that enhanced dynorphin signaling causes reduced inhibition onto these neurons. These results suggest that similar cellular and circuit changes are involved in the enhanced anxiety induced by stress and that observed in the ErbB4 mutant mice. 


\section{Discussion}

The responses driven by anxiety are evolutionarily conserved and are essential for animals and humans to survive. However, excessive anxiety, like that occurring in anxiety disorders, is maladaptive. The central extended amygdala, which encompasses the CeA and the BNST (Alheid and Heimer, 1988), is thought to play a crucial role in regulating aspects of anxiety. It was previously proposed that the CeA and the BNST separately regulate fear and anxiety, respectively (Walker and Davis, 2008; Davis et al., 2010). On the other hand, recent evidence indicates that enhanced activity in the CeA is also associated with the generation of anxiety (Shackman et al., 2013; Shackman and Fox, 2016). Nevertheless, how the CeA contributes to anxiety-related behaviors and how its dysfunction participates in the development of maladaptive anxiety remain unclear.

In this study, we took advantage of mice that show heightened anxiety due to selective deletion of Erbb4 - a gene that has been implicated in the development, function, and disorders of the CNS (Mei and Xiong, 2008; Mei and Nave, 2014)—in SOM ${ }^{+}$ neurons. We found that excitatory synaptic transmission onto $\mathrm{SOM}^{+} \mathrm{CeL}$ neurons in the ErbB4 mutant mice, including the $S_{0 m}{ }^{E r b b 4+1-}$ (HET) and Som ${ }^{E r b b 4-1-}(\mathrm{KO})$ mice, was enhanced compared with that in the Som ${ }^{E r b b 4+/+}$ (WT) mice, and that this synaptic change was both necessary and sufficient for the anxiety phenotypes of the mutant mice.

The increased excitatory drive onto $\mathrm{SOM}^{+} \mathrm{CeL}$ neurons, a population that normally provides GABAergic inhibition onto $\mathrm{SOM}^{+} \mathrm{dBNST}$ neurons, in the mutant mice caused a paradoxical decrease in inhibition onto and thus an increase in the activity of $\mathrm{SOM}^{+}$dBNST neurons, thereby leading to the heightened anxiety. Previous findings on the role of dynorphin signaling in negatively regulating the GABAergic inputs to the BNST (Li et al., 2012; Crowley et al., 2016) prompted us to investigate changes in this signaling pathway in the mutant mice. Indeed, we found that the disinhibition of $\mathrm{SOM}^{+}$dBNST neurons and the heightened anxiety were associated with and dependent on increased dynorphin signaling in the CeL and the dBNST. Finally, we found that the increased anxiety induced by stress in wild-type mice involved mechanisms that were similar to those operating in the ErbB4 mutant mice, including the enhanced excitatory drive onto $\mathrm{SOM}^{+} \mathrm{CeL}$ neurons and the dynorphin-mediated disinhibition of $\mathrm{SOM}^{+} \mathrm{dBNST}$ neurons. Of note, our results are fully consistent with those in recent studies, which strongly indicate that dynorphin signaling in the BNST (Li et al., 2012; Crowley et al., 2016), amygdaloid complex (Land et al., 2008; Bruchas et al., 2009; Crowley et al., 2016; Nygard et al., 2016), and nucleus accumbens (Land et al., 2008; Al-Hasani et al., 2015) plays important roles in aversion, stress, and anxiety (Bruchas and Chavkin, 2010; Bruchas et al., 2010; Crowley and Kash, 2015).

Recent studies indicate that $\mathrm{SOM}^{+} \mathrm{CeA}$ neurons are critical for learning passive defensive behaviors during fear conditioning (Li et al., 2013; Penzo et al., 2014, 2015; Yu et al., 2016, 2017; Fadok et al., 2017) as well as for reward-seeking behaviors (Douglass et al., 2017; Kim et al., 2017). These findings, together with the current results, suggest that $\mathrm{SOM}^{+} \mathrm{CeA}$ neurons have heterogeneous functions, which are likely mediated by subpopulations of these neurons embedded within distinct circuits. Similar heterogeneity has also been observed in another major population of the $\mathrm{CeA}$, the protein kinase $\mathrm{C}-\delta$-expressing CeA neurons, which plays important roles in regulating both aversive learning (Cui et al., 2017; Yu et al., 2017) and feeding behaviors (Cai et al., 2014).
Together, our results reveal circuit and cellular mechanisms in the central extended amygdala that may underlie maladaptive anxiety related to anxiety disorders. Neurons in the dBNST, including the $\mathrm{SOM}^{+}$neurons, may regulate anxiety by either their projections to the midbrain, or through interactions with neurons in other BNST nuclei, such as the anterodorsal BNST (Kim et al., 2013) and the ventral BNST (Jennings et al., 2013), which have been shown to influence anxiety-related behaviors. Future studies are needed to elucidate the precise behavioral roles of each of the BNST nuclei and the distinct neuronal populations therein.

\section{References}

Ahrens S, Jaramillo S, Yu K, Ghosh S, Hwang GR, Paik R, Lai C, He M, Huang ZJ, Li B (2015) ErbB4 regulation of a thalamic reticular nucleus circuit for sensory selection. Nat Neurosci 18:104-111. CrossRef Medline

Al-Hasani R, McCall JG, Shin G, Gomez AM, Schmitz GP, Bernardi JM, Pyo CO, Park SI, Marcinkiewcz CM, Crowley NA, Krashes MJ, Lowell BB, Kash TL, Rogers JA, Bruchas MR (2015) Distinct subpopulations of nucleus accumbens dynorphin neurons drive aversion and reward. Neuron 87:1063-1077. CrossRef Medline

Alheid GF, Heimer L (1988) New perspectives in basal forebrain organization of special relevance for neuropsychiatric disorders: the striatopallidal, amygdaloid, and corticopetal components of substantia innominata. Neuroscience 27:1-39. CrossRef Medline

Andreatta M, Glotzbach-Schoon E, Mühlberger A, Schulz SM, Wiemer J, Pauli P (2015) Initial and sustained brain responses to contextual conditioned anxiety in humans. Cortex 63:352-363. CrossRef Medline

Batista-Brito R, Vinck M, Ferguson KA, Chang JT, Laubender D, Lur G, Mossner JM, Hernandez VG, Ramakrishnan C, Deisseroth K, Higley MJ, Cardin JA (2017) Developmental dysfunction of vip interneurons impairs cortical circuits. Neuron 95:884-895.e9. CrossRef Medline

Belzung C, Griebel G (2001) Measuring normal and pathological anxietylike behaviour in mice: a review. Behav Brain Res 125:141-149. CrossRef Medline

Blanchard DC, Griebel G, Blanchard RJ (2001) Mouse defensive behaviors: pharmacological and behavioral assays for anxiety and panic. Neurosci Biobehav Rev 25:205-218. CrossRef Medline

Bruchas MR, Chavkin C (2010) Kinase cascades and ligand-directed signaling at the kappa opioid receptor. Psychopharmacology (Berl) 210:137147. CrossRef Medline

Bruchas MR, Land BB, Lemos JC, Chavkin C (2009) CRF1-R activation of the dynorphin/kappa opioid system in the mouse basolateral amygdala mediates anxiety-like behavior. PLoS One 4:e8528. CrossRef Medline

Bruchas MR, Land BB, Chavkin C (2010) The dynorphin/kappa opioid system as a modulator of stress-induced and pro-addictive behaviors. Brain Res 1314:44-55. CrossRef Medline

Cai H, Haubensak W, Anthony TE, Anderson DJ (2014) Central amygdala PKC-delta(+) neurons mediate the influence of multiple anorexigenic signals. Nat Neurosci 17:1240-1248. CrossRef Medline

Calhoon GG, Tye KM (2015) Resolving the neural circuits of anxiety. Nat Neurosci 18:1394-1404. CrossRef Medline

Cassell MD, Gray TS (1989) Morphology of peptide-immunoreactive neurons in the rat central nucleus of the amygdala. J Comp Neurol 281:320 333. CrossRef Medline

Christie LA, Russell TA, Xu J, Wood L, Shepherd GM, Contractor A (2010) AMPA receptor desensitization mutation results in severe developmental phenotypes and early postnatal lethality. Proc Natl Acad Sci U S A 107: 9412-9417. CrossRef Medline

Crowley NA, Kash TL (2015) Kappa opioid receptor signaling in the brain: circuitry and implications for treatment. Prog Neuropsychopharmacol Biol Psychiatry 62:51-60. CrossRef Medline

Crowley NA, Bloodgood DW, Hardaway JA, Kendra AM, McCall JG, AlHasani R, McCall NM, Yu W, Schools ZL, Krashes MJ, Lowell BB, Whistler JL, Bruchas MR, Kash TL (2016) Dynorphin controls the gain of an amygdalar anxiety circuit. Cell Rep 14:2774-2783. CrossRef Medline

Cui Y, Lv G, Jin S, Peng J, Yuan J, He X, Gong H, Xu F, Xu T, Li H (2017) A central amygdala-substantia innominata neural circuitry encodes aversive reinforcement signals. Cell Rep 21:1770-1782. CrossRef Medline

Davis M, Walker DL, Miles L, Grillon C (2010) Phasic vs sustained fear in rats and humans: role of the extended amygdala in fear vs anxiety. Neuropsychopharmacology 35:105-135. CrossRef Medline 
Dobin A, Davis CA, Schlesinger F, Drenkow J, Zaleski C, Jha S, Batut P, Chaisson M, Gingeras TR (2013) STAR: ultrafast universal RNA-seq aligner. Bioinformatics 29:15-21. CrossRef Medline

Donahue RJ, Landino SM, Golden SA, Carroll FI, Russo SJ, Carlezon WA Jr (2015) Effects of acute and chronic social defeat stress are differentially mediated by the dynorphin/kappa-opioid receptor system. Behav Pharmacol 26:654-663. CrossRef Medline

Douglass AM, Kucukdereli H, Ponserre M, Markovic M, Gründemann J, Strobel C, Alcala Morales PL, Conzelmann KK, Lüthi A, Klein R (2017) Central amygdala circuits modulate food consumption through a positive-valence mechanism. Nat Neurosci 20:1384-1394. CrossRef Medline

Duvarci S, Pare D (2014) Amygdala microcircuits controlling learned fear. Neuron 82:966-980. CrossRef Medline

Etkin A (2010) Functional neuroanatomy of anxiety: a neural circuit perspective. Curr Top Behav Neurosci 2:251-277. Medline

Etkin A, Wager TD (2007) Functional neuroimaging of anxiety: a metaanalysis of emotional processing in PTSD, social anxiety disorder, and specific phobia. Am J Psychiatry 164:1476-1488. CrossRef Medline

Fadok JP, Krabbe S, Markovic M, Courtin J, Xu C, Massi L, Botta P, Bylund K, Müller C, Kovacevic A, Tovote P, Lüthi A (2017) A competitive inhibitory circuit for selection of active and passive fear responses. Nature 542: 96-100. CrossRef Medline

Fazzari P, Paternain AV, Valiente M, Pla R, Luján R, Lloyd K, Lerma J, Marín O, Rico B (2010) Control of cortical GABA circuitry development by Nrgl and ErbB4 signalling. Nature 464:1376-1380. CrossRef Medline

Fox AS, Kalin NH (2014) A translational neuroscience approach to understanding the development of social anxiety disorder and its pathophysiology. Am J Psychiatry 171:1162-1173. CrossRef Medline

Fox AS, Oler JA, Tromp do PM, Fudge JL, Kalin NH (2015) Extending the amygdala in theories of threat processing. Trends Neurosci 38:319-329. CrossRef Medline

Golub MS, Germann SL, Lloyd KC (2004) Behavioral characteristics of a nervous system-specific erbB4 knock-out mouse. Behav Brain Res 153: 159-170. CrossRef Medline

Gray TS, Magnuson DJ (1992) Peptide immunoreactive neurons in the amygdala and the bed nucleus of the stria terminalis project to the midbrain central gray in the rat. Peptides 13:451-460. CrossRef Medline

Gungor NZ, Paré D (2016) Functional heterogeneity in the bed nucleus of the stria terminalis. J Neurosci 36:8038-8049. CrossRef Medline

He M, Liu Y, Wang X, Zhang MQ, Hannon GJ, Huang ZJ (2012) Cell-typebased analysis of microRNA profiles in the mouse brain. Neuron 73:3548. CrossRef Medline

Heiman M, Kulicke R, Fenster RJ, Greengard P, Heintz N (2014) Cell typespecific mRNA purification by translating ribosome affinity purification (TRAP). Nat Protoc 9:1282-1291. CrossRef Medline

Herry C, Johansen JP (2014) Encoding of fear learning and memory in distributed neuronal circuits. Nat Neurosci 17:1644-1654. CrossRef Medline

Hsieh H, Boehm J, Sato C, Iwatsubo T, Tomita T, Sisodia S, Malinow R (2006) AMPAR removal underlies abeta-induced synaptic depression and dendritic spine loss. Neuron 52:831-843. CrossRef Medline

Jennings JH, Sparta DR, Stamatakis AM, Ung RL, Pleil KE, Kash TL, Stuber GD (2013) Distinct extended amygdala circuits for divergent motivational states. Nature 496:224-228. CrossRef Medline

Kash TL, Pleil KE, Marcinkiewcz CA, Lowery-Gionta EG, Crowley N, Mazzone C, Sugam J, Hardaway JA, McElligott ZA (2015) Neuropeptide regulation of signaling and behavior in the BNST. Mol Cells 38:1-13. CrossRef Medline

Kim SY, Adhikari A, Lee SY, Marshel JH, Kim CK, Mallory CS, Lo M, Pak S, Mattis J, Lim BK, Malenka RC, Warden MR, Neve R, Tye KM, Deisseroth K (2013) Diverging neural pathways assemble a behavioural state from separable features in anxiety. Nature 496:219-223. CrossRef Medline

Kim J, Zhang X, Muralidhar S, LeBlanc SA, Tonegawa S (2017) Basolateral to central amygdala neural circuits for appetitive behaviors. Neuron 93: 1464-1479.e5. CrossRef Medline

Knoll AT, Meloni EG, Thomas JB, Carroll FI, Carlezon WA Jr (2007) Anxiolytic-like effects of kappa-opioid receptor antagonists in models of unlearned and learned fear in rats. J Pharmacol Exp Ther 323:838-845. CrossRef Medline

Knoll AT, Carlezon WA Jr (2010) Dynorphin, stress, and depression. Brain Res 1314:56-73. CrossRef Medline
Kopec CD, Li B, Wei W, Boehm J, Malinow R (2006) Glutamate receptor exocytosis and spine enlargement during chemically induced long-term potentiation. J Neurosci 26:2000-2009. CrossRef Medline

Land BB, Bruchas MR, Lemos JC, Xu M, Melief EJ, Chavkin C (2008) The dysphoric component of stress is encoded by activation of the dynorphin $\kappa$-opioid system. J Neurosci 28:407-414. CrossRef Medline

Lein ES, Hawrylycz MJ, Ao N, Ayres M, Bensinger A, Bernard A, Boe AF, Boguski MS, Brockway KS, Byrnes EJ, Chen L, Chen L, Chen TM, Chin MC, Chong J, Crook BE, Czaplinska A, Dang CN, Datta S, Dee NR, et al. (2007) Genome-wide atlas of gene expression in the adult mouse brain. Nature 445:168-176. CrossRef Medline

Li C, Pleil KE, Stamatakis AM, Busan S, Vong L, Lowell BB, Stuber GD, Kash TL (2012) Presynaptic inhibition of gamma-aminobutyric acid release in the bed nucleus of the stria terminalis by kappa opioid receptor signaling. Biol Psychiatry 71:725-732. CrossRef Medline

Li H, Penzo MA, Taniguchi H, Kopec CD, Huang ZJ, Li B (2013) Experience-dependent modification of a central amygdala fear circuit. Nat Neurosci 16:332-339. CrossRef Medline

Liao Y, Smyth GK, Shi W (2014) featureCounts: an efficient general purpose program for assigning sequence reads to genomic features. Bioinformatics 30:923-930. CrossRef Medline

Love MI, Huber W, Anders S (2014) Moderated estimation of fold change and dispersion for RNA-seq data with DESeq2. Genome Biol 15:550. CrossRef Medline

Lu Y, Sun XD, Hou FQ, Bi LL, Yin DM, Liu F, Chen YJ, Bean JC, Jiao HF, Liu X, Li BM, Xiong WC, Gao TM, Mei L (2014) Maintenance of GABAergic activity by neuregulin 1-ErbB4 in amygdala for fear memory. Neuron 84:835-846. CrossRef Medline

Madisen L, Zwingman TA, Sunkin SM, Oh SW, Zariwala HA, Gu H, Ng LL, Palmiter RD, Hawrylycz MJ, Jones AR, Lein ES, Zeng H (2010) A robust and high-throughput cre reporting and characterization system for the whole mouse brain. Nat Neurosci 13:133-140. CrossRef Medline

Marchant NJ, Densmore VS, Osborne PB (2007) Coexpression of prodynorphin and corticotrophin-releasing hormone in the rat central amygdala: evidence of two distinct endogenous opioid systems in the lateral division. J Comp Neurol 504:702-715. CrossRef Medline

Marcinkiewcz CA, Mazzone CM, D’Agostino G, Halladay LR, Hardaway JA, DiBerto JF, Navarro M, Burnham N, Cristiano C, Dorrier CE, Tipton GJ, Ramakrishnan C, Kozicz T, Deisseroth K, Thiele TE, McElligott ZA, Holmes A, Heisler LK, Kash TL (2016) Serotonin engages an anxiety and fear-promoting circuit in the extended amygdala. Nature 537:97-101. CrossRef Medline

McCall JG, Al-Hasani R, Siuda ER, Hong DY, Norris AJ, Ford CP, Bruchas MR (2015) CRH engagement of the locus coeruleus noradrenergic system mediates stress-induced anxiety. Neuron 87:605-620. CrossRef Medline

McLaughlin KA, Busso DS, Duys A, Green JG, Alves S, Way M, Sheridan MA (2014) Amygdala response to negative stimuli predicts PTSD symptom onset following a terrorist attack. Depress Anxiety 31:834-842. CrossRef Medline

Mei L, Nave KA (2014) Neuregulin-ERBB signaling in the nervous system and neuropsychiatric diseases. Neuron 83:27-49. CrossRef Medline

Mei L, Xiong WC (2008) Neuregulin 1 in neural development, synaptic plasticity and schizophrenia. Nat Rev Neurosci 9:437-452. CrossRef Medline

Mobbs D, Yu R, Rowe JB, Eich H, FeldmanHall O, Dalgleish T (2010) Neural activity associated with monitoring the oscillating threat value of a tarantula. Proc Natl Acad Sci U S A 107:20582-20586. CrossRef Medline

Murray AJ, Sauer JF, Riedel G, McClure C, Ansel L, Cheyne L, Bartos M, Wisden W, Wulff P (2011) Parvalbumin-positive CA1 interneurons are required for spatial working but not for reference memory. Nat Neurosci 14:297-299. CrossRef Medline

Neddens J, Buonanno A (2011) Expression of the neuregulin receptor ErbB4 in the brain of the rhesus monkey (Macaca mulatta). PLoS One 6:e27337. CrossRef Medline

Nygard SK, Hourguettes NJ, Sobczak GG, Carlezon WA, Bruchas MR (2016) Stress-induced reinstatement of nicotine preference requires dynorphin/ $\kappa$ opioid activity in the basolateral amygdala. J Neurosci 36:99379948. CrossRef Medline

Oler JA, Tromp DP, Fox AS, Kovner R, Davidson RJ, Alexander AL, McFarlin DR, Birn RM, E Berg B, deCampo DM, Kalin NH, Fudge JL (2017) Connectivity between the central nucleus of the amygdala and the bed 
nucleus of the stria terminalis in the non-human primate: neuronal tract tracing and developmental neuroimaging studies. Brain Struct Funct 222: 21-39. CrossRef Medline

Penzo MA, Robert V, Li B (2014) Fear conditioning potentiates synaptic transmission onto long-range projection neurons in the lateral subdivision of central amygdala. J Neurosci 34:2432-2437. CrossRef Medline

Penzo MA, Robert V, Tucciarone J, De Bundel D, Wang M, Van Aelst L, Darvas M, Parada LF, Palmiter RD, He M, Huang ZJ, Li B (2015) The paraventricular thalamus controls a central amygdala fear circuit. Nature 519:455-459. CrossRef Medline

Perova Z, Delevich K, Li B (2015) Depression of excitatory synapses onto parvalbumin interneurons in the medial prefrontal cortex in susceptibility to stress. J Neurosci 35:3201-3206 CrossRef Medline

Poulin JF, Arbour D, Laforest S, Drolet G (2009) Neuroanatomical characterization of endogenous opioids in the bed nucleus of the stria terminalis. Prog Neuropsychopharmacol Biol Psychiatry 33:1356-1365. CrossRef Medline

Sanford CA, Soden ME, Baird MA, Miller SM, Schulkin J, Palmiter RD, Clark M, Zweifel LS (2017) A central amygdala CRF circuit facilitates learning about weak threats. Neuron 93:164-178. CrossRef Medline

Sanz E, Yang L, Su T, Morris DR, McKnight GS, Amieux PS (2009) Celltype-specific isolation of ribosome-associated mRNA from complex tissues. Proc Natl Acad Sci U S A 106:13939-13944. CrossRef Medline

Shackman AJ, Fox AS (2016) Contributions of the central extended amygdala to fear and anxiety. J Neurosci 36:8050-8063. CrossRef Medline

Shackman AJ, Fox AS, Oler JA, Shelton SE, Davidson RJ, Kalin NH (2013) Neural mechanisms underlying heterogeneity in the presentation of anxious temperament. Proc Natl Acad Sci U S A 110:6145-6150. CrossRef Medline

Stamatakis AM, Sparta DR, Jennings JH, McElligott ZA, Decot H, Stuber GD (2014) Amygdala and bed nucleus of the stria terminalis circuitry: implications for addiction-related behaviors. Neuropharmacology 76:320328. CrossRef Medline

Stephenson-Jones M, Yu K, Ahrens S, Tucciarone JM, van Huijstee AN, Mejia LA, Penzo MA, Tai LH, Wilbrecht L, Li B (2016) A basal ganglia circuit for evaluating action outcomes. Nature 539:289-293. CrossRef Medline

Taniguchi H, He M, Wu P, Kim S, Paik R, Sugino K, Kvitsani D, Fu Y, Lu J, Lin Y, Miyoshi G, Shima Y, Fishell G, Nelson SB, Huang ZJ (2011) A resource of cre driver lines for genetic targeting of GABAergic neurons in cerebral cortex. Neuron 71:995-1013. CrossRef Medline

Tovote P, Fadok JP, Lüthi A (2015) Neuronal circuits for fear and anxiety. Nat Rev Neurosci 16:317-331. CrossRef Medline

Vullhorst D, Neddens J, Karavanova I, Tricoire L, Petralia RS, McBain CJ,
Buonanno A (2009) Selective expression of ErbB4 in interneurons, but not pyramidal cells, of the rodent hippocampus. J Neurosci 29:1225512264. CrossRef Medline

Wager T, Barrett L, Bliss-Moreau E, Lindquist K, Duncan S, Kober H, Joseph J, Davidson M, Mize J (2008) The neuroimaging of emotion. In: The handbook of emotion, Ed 3 (Lewis M, Haviland-Jones JM, Barrett LF, eds), pp 249-271. New York, NY: Guilford.

Walker DL, Davis M (2008) Role of the extended amygdala in shortduration versus sustained fear: a tribute to Dr. Lennart Heimer. Brain Struct Funct 213:29-42. CrossRef Medline

Wang M, Perova Z, Arenkiel BR, Li B (2014) Synaptic modifications in the medial prefrontal cortex in susceptibility and resilience to stress. J Neurosci 34:7485-7492. CrossRef Medline

Weston MC, Schuck P, Ghosal A, Rosenmund C, Mayer ML (2006) Conformational restriction blocks glutamate receptor desensitization. Nat Struct Mol Biol 13:1120-1127. CrossRef Medline

Wittmann W, Schunk E, Rosskothen I, Gaburro S, Singewald N, Herzog H, Schwarzer C (2009) Prodynorphin-derived peptides are critical modulators of anxiety and regulate neurochemistry and corticosterone. Neuropsychopharmacology 34:775-785. CrossRef Medline

Wulff P, Goetz T, Leppa E, Linden AM, Renzi M, Swinny JD, Vekovischeva OY, Sieghart W, Somogyi P, Korpi ER, Farrant M, Wisden W (2007) From synapse to behavior: rapid modulation of defined neuronal types with engineered GABAA receptors. Nat Neurosci 10:923-929. CrossRef Medline

Yu K, Garcia da Silva P, Albeanu DF, Li B (2016) Central amygdala somatostatin neurons gate passive and active defensive behaviors. J Neurosci 36:6488-6496. CrossRef Medline

Yu K, Ahrens S, Zhang X, Schiff H, Ramakrishnan C, Fenno L, Deisseroth K, Zhao F, Luo MH, Gong L, He M, Zhou P, Paninski L, Li B (2017) The central amygdala controls learning in the lateral amygdala. Nat Neurosci 20:1680-1685. CrossRef Medline

Yue F, Cheng Y, Breschi A, Vierstra J, Wu W, Ryba T, Sandstrom R, Ma Z, Davis C, Pope BD, Shen Y, Pervouchine DD, Djebali S, Thurman RE, Kaul R, Rynes E, Kirilusha A, Marinov GK, Williams BA, Trout D, et al. (2014) A comparative encyclopedia of DNA elements in the mouse genome. Nature 515:355-364. CrossRef Medline

Zhang F, Wang LP, Boyden ES, Deisseroth K (2006) Channelrhodopsin-2 and optical control of excitable cells. Nat Methods 3:785-792. CrossRef Medline

Zhu JJ, Esteban JA, Hayashi Y, Malinow R (2000) Postnatal synaptic potentiation: delivery of GluR4-containing AMPA receptors by spontaneous activity. Nat Neurosci 3:1098-1106. CrossRef Medline 